DOE/NASA/2593.79/12

NASA TM-79309

\title{
EFFECT OF SODIUM, POTASSIUM, MAGNESIUM, CALCIUM, AND ChloRINE ON THE hIOH TEMPERATURE CORROSION OF IN-100, U-700, IN-792, AND MAR M-509
}

Carl E. Lowell, Steven M. Sidik, And Daniel L. Deadmore National Aeronautics and Space Administration Le'vis Research Center

Work performed for U.S. DEPARTMENT OF ENERGY Energy Technology Fossil Fuel Utilization Division
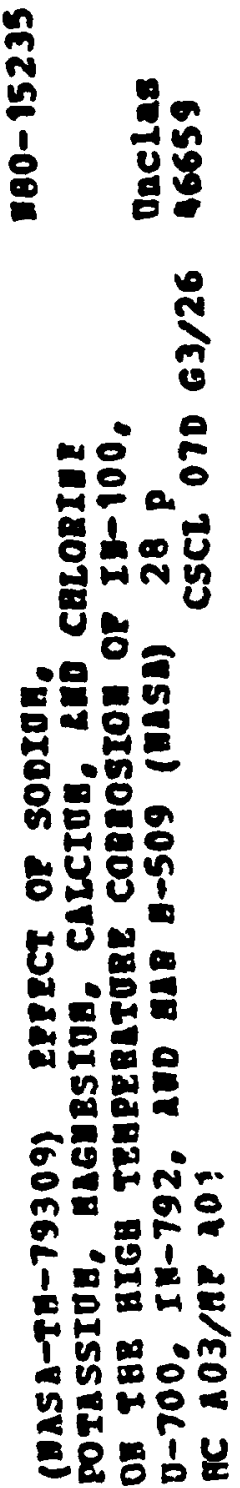

Prepared for

Twenty-fitth Annual International

Gas Turbine Conference sponsored by the American Society of Mechanical Engineers New Orleans, Louisiana, March 9-13, 1980 
EFFECI OF SODIUM, POTASSIUM, MAGNESIUM. CALCIUM, AND

CHLORINE ON THE HIGH

TEMPERATURE CORROSION OF

OF $\mathbb{N}-100, U \cdot 700, \mathbb{N} \cdot 79 \%$,

AND MAR M-509

Carl E. Lowell, Steven M. Sidik, and Daniel $L$. Deadmore

National Aeronaulics and Space Administration

Lewis Research Center

Cleveland, Onio 44135

Prepared for

U.S. DEPARTMENI — ENERGY

Energy Technology

Fossil Fuel Utilizalion Division

Washington, D.C. 20545

Under Inleragency Agreement EF - $77 \cdot A-01 \cdot 2593$

Twenty-fifth Annual International

Gas Turbine Conference sponsored by the American Sociely of Mechanical Engineers New Orleans, Louisiana, March 9-13, 1980 


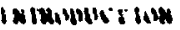

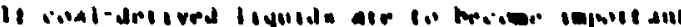

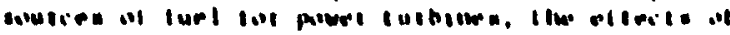

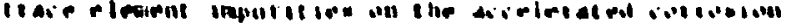

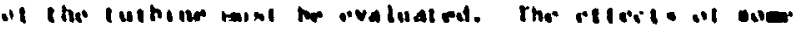

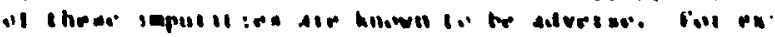

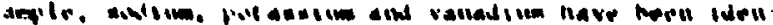

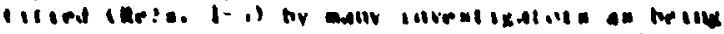

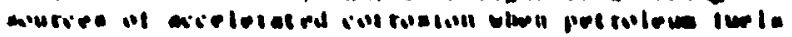

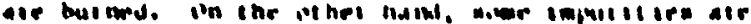

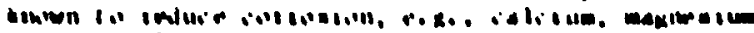

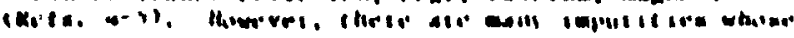

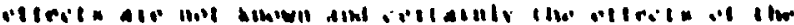

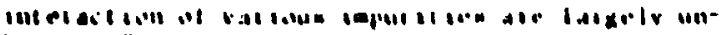

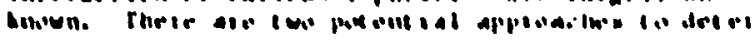

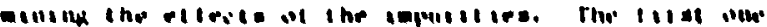

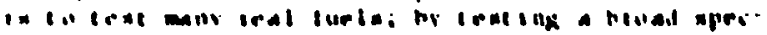

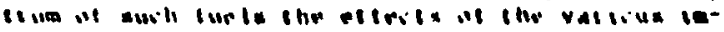

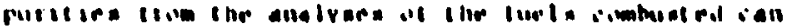

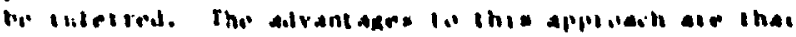

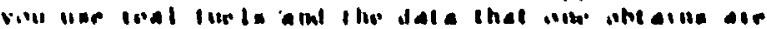

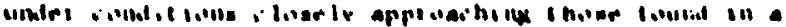

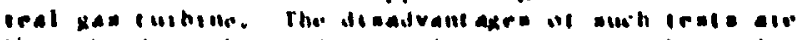

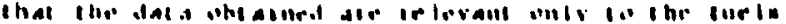

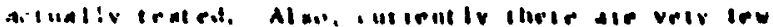

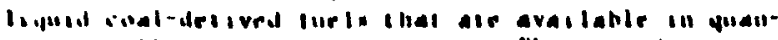

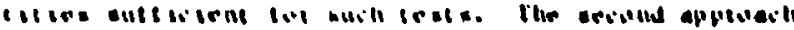

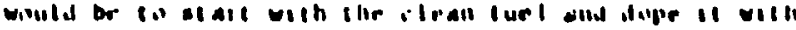

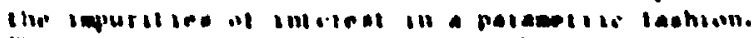

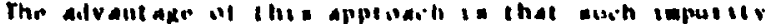

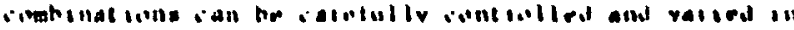

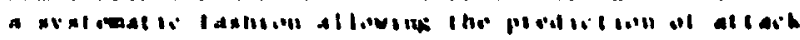

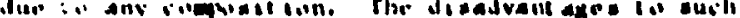

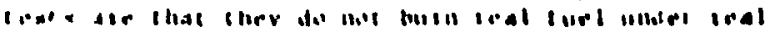

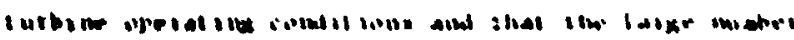

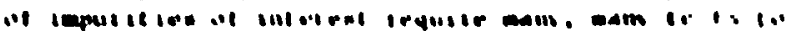
ho mals.

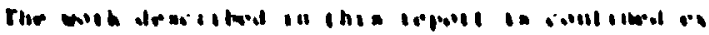

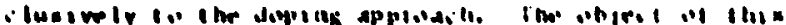

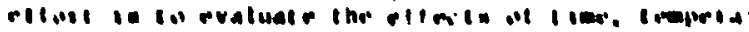

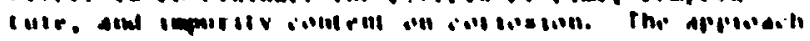

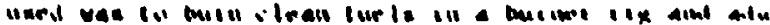

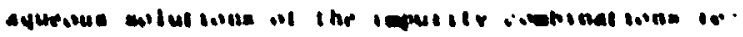

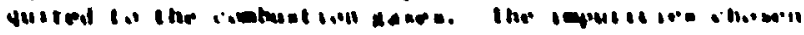

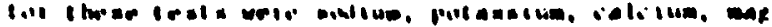

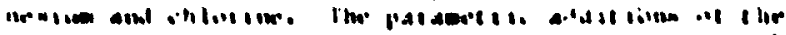

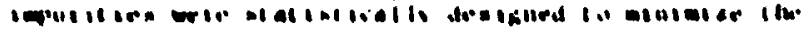

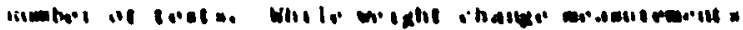

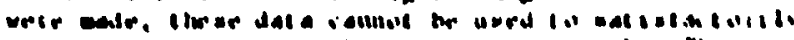

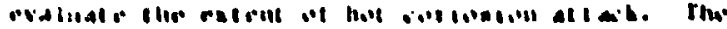

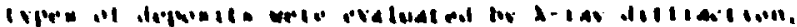

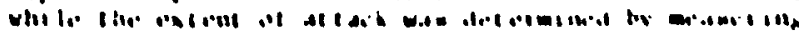

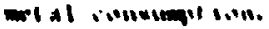

\section{MTRKIAIS}

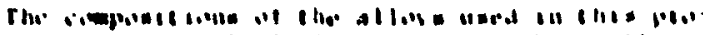

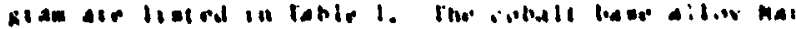

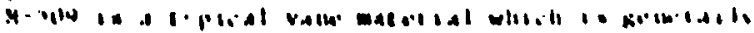

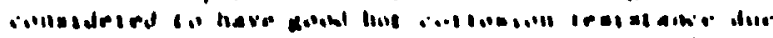

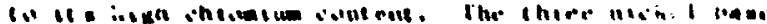

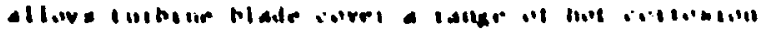

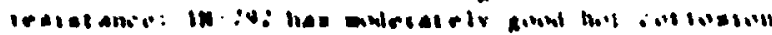

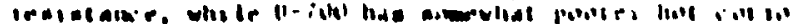

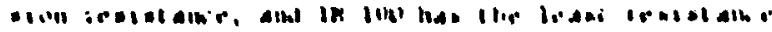

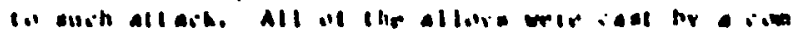

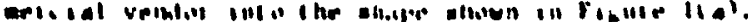

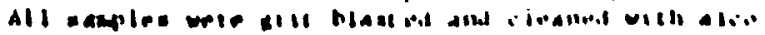

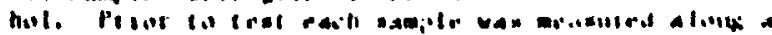

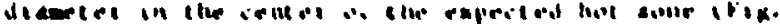

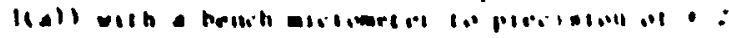

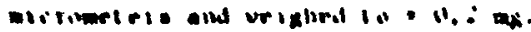




\section{nowsoun}

A mareme ris irpical wi thr fout weod for thot

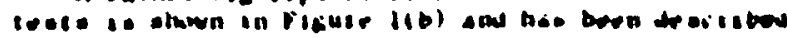

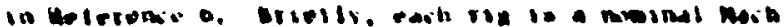

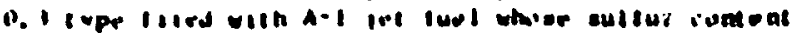

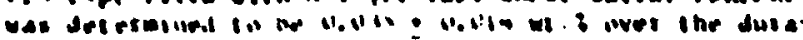

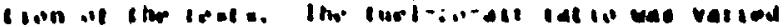

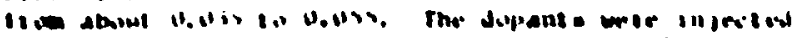

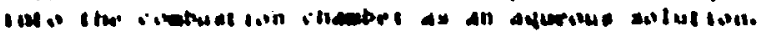

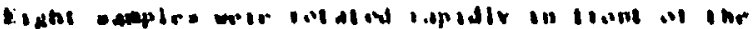

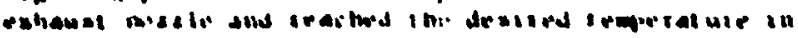

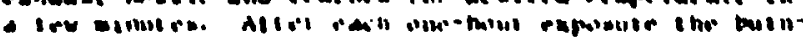

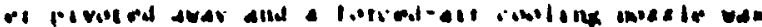

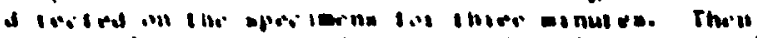

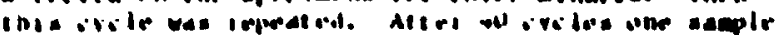

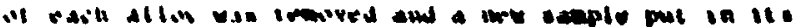

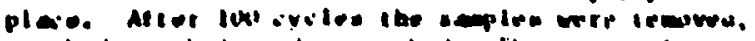

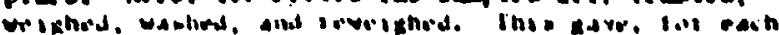

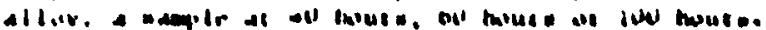

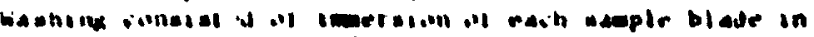

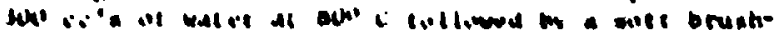

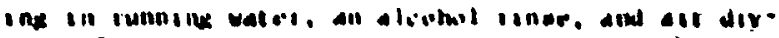

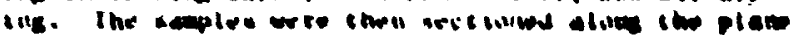

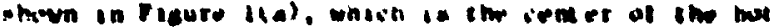

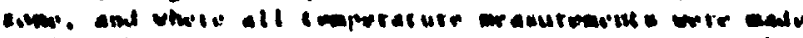

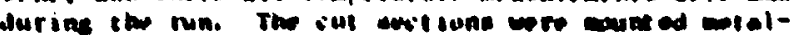

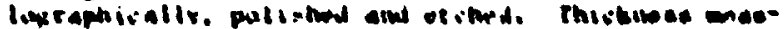

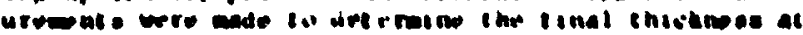

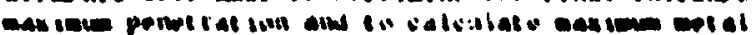

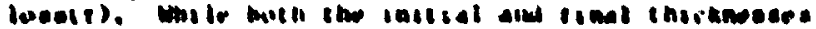

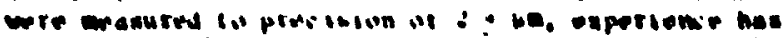

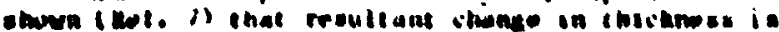

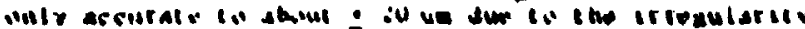

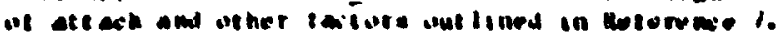

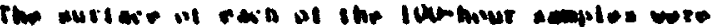

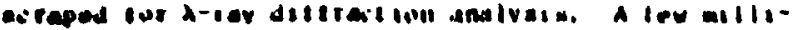

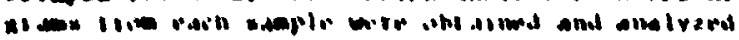

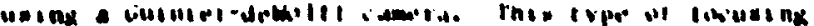

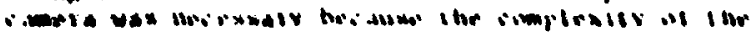

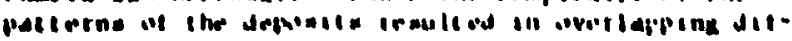
It action linet.

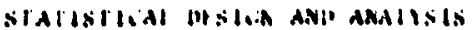

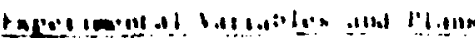

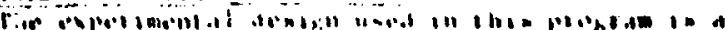

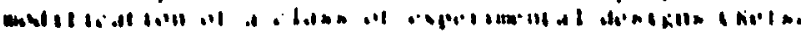

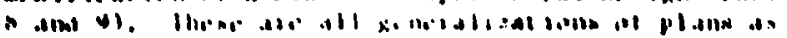

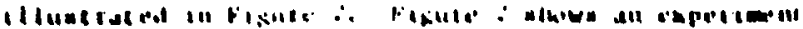

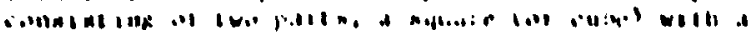

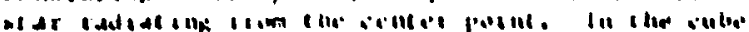

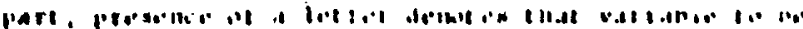

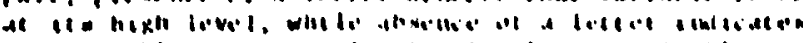

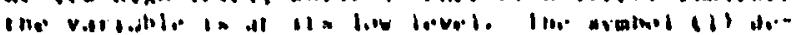

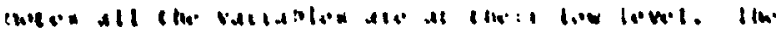

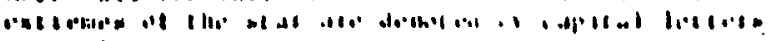
Hisli plut al wilust.

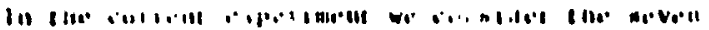

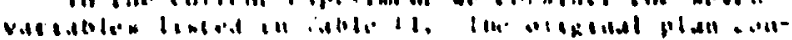

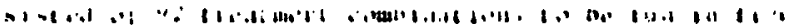

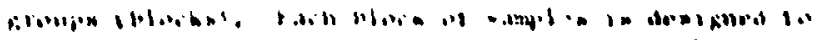

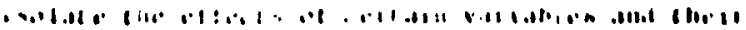

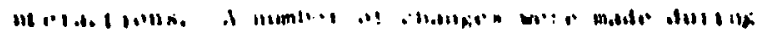

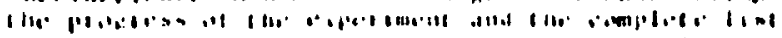

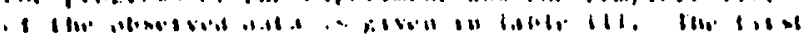

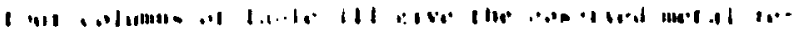

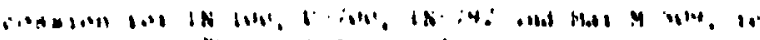

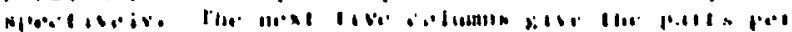

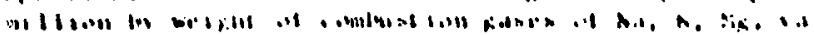

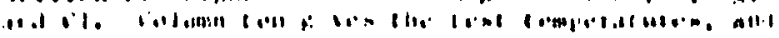

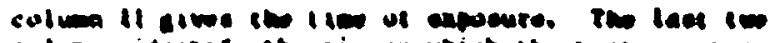

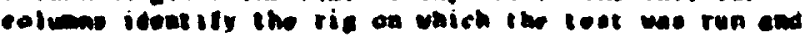

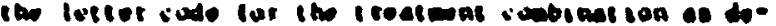

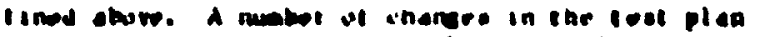

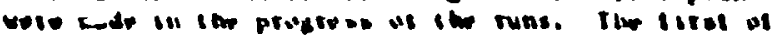

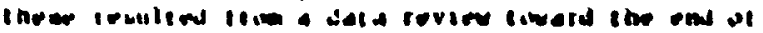

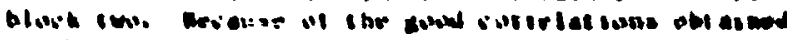

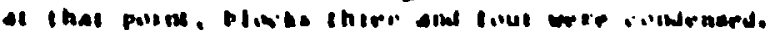

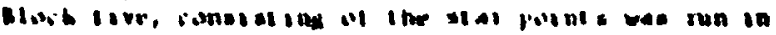
11 a entite: $v$.

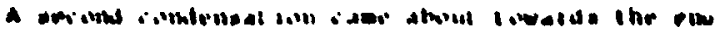

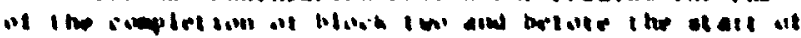

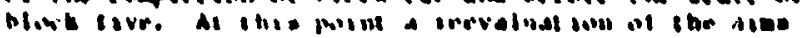

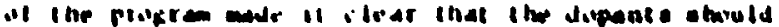

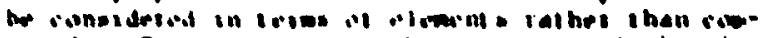

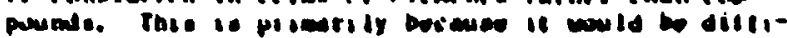

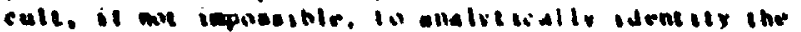

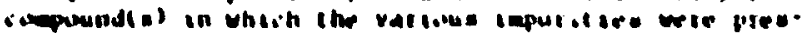

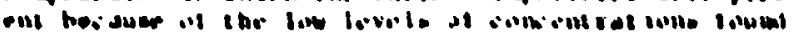
in limer lurle.

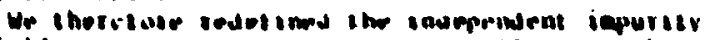

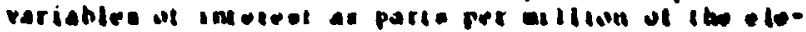

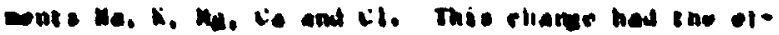

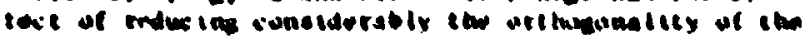

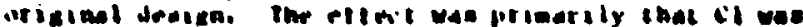

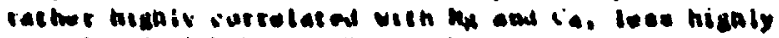

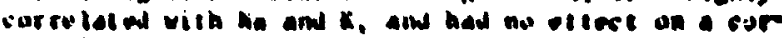

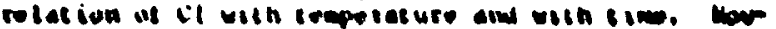

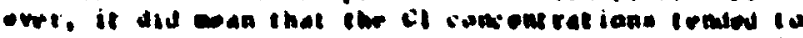

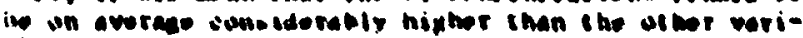
dbles, This epprienth had listle eftect an fil of the dest.

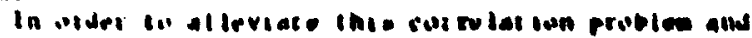

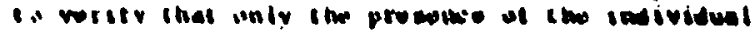

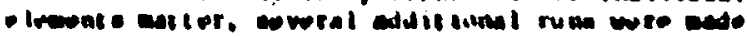

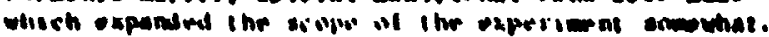

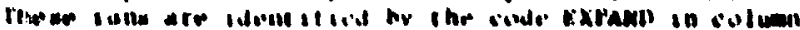

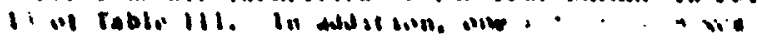
male vith in atopant a, that is. owiu ...

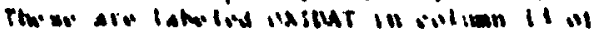

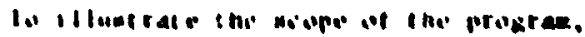

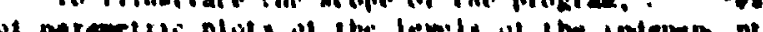

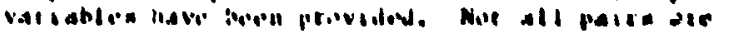

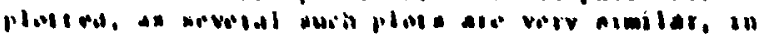

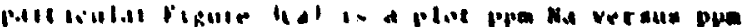

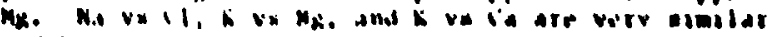

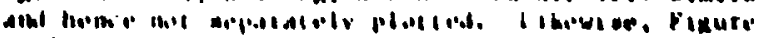

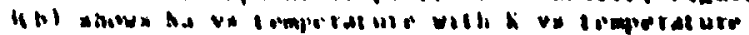

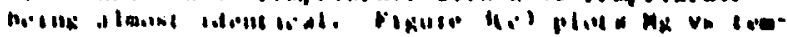

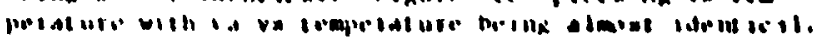

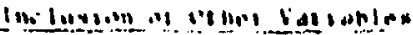

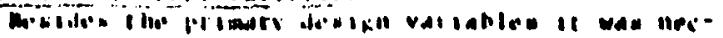

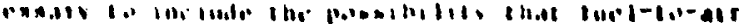

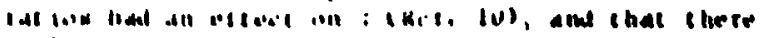

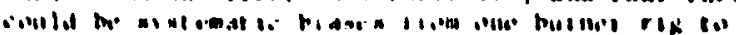

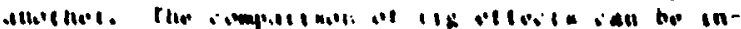

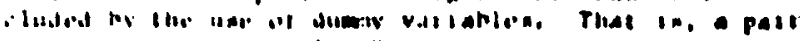

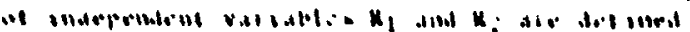

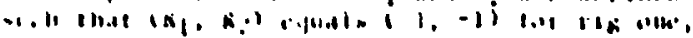

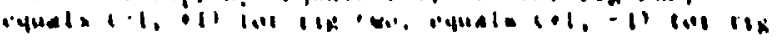

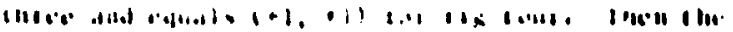

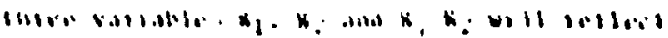

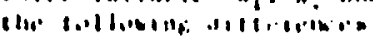

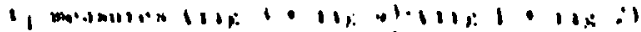

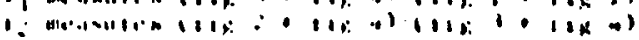

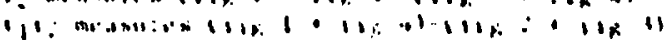

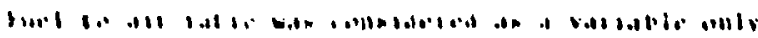

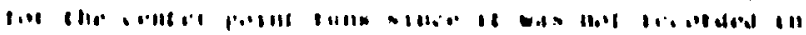

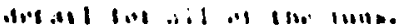




\section{vepe ef the cener boine}

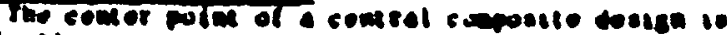

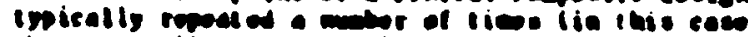

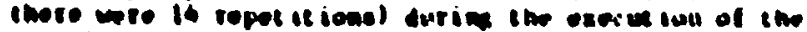

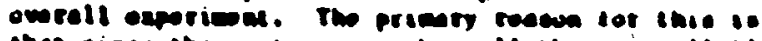

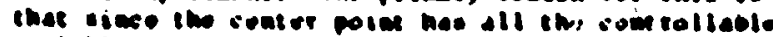

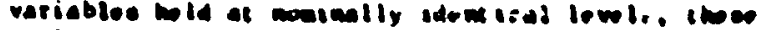
repliceres pruvide infureat ion on: I da imieponieat

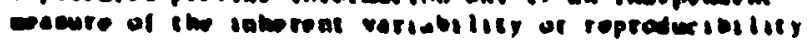

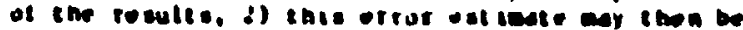

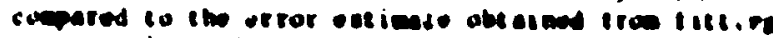

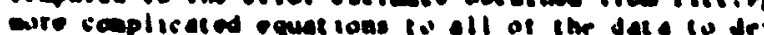

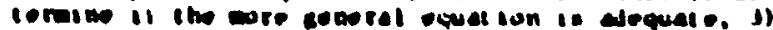
it the center wints are int ol speres in t cer thea

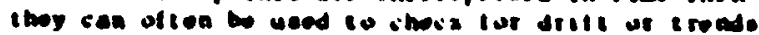

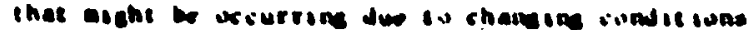

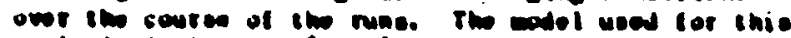

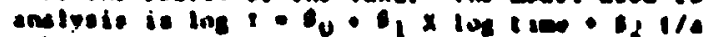

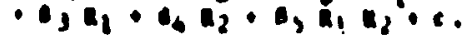

\section{Dull pere subleit.}

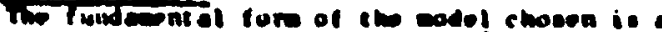
power las in tien, that ie, ro a tad uthere the rate eanateat al is a funstion of tho rosernim ver-

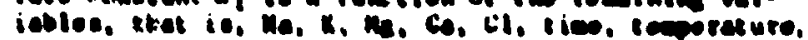

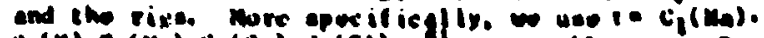

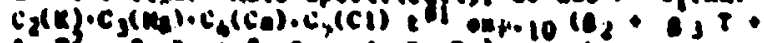

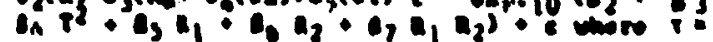

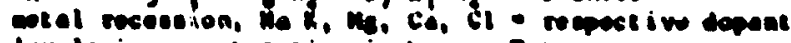

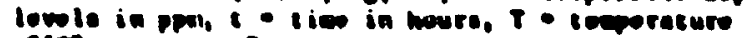

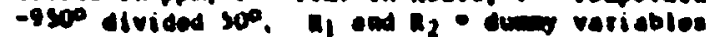

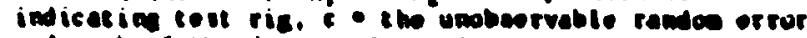
and oach of the $i_{i}$ are of the ture:

\section{$c_{i} \cdot\left(A_{i 1} \cdot\left(1-\theta_{11}\right) \exp \left(-a_{i 2}\right)\right.$}

Thio funsional torn has the fuilowne prop-rt ies: A) it is coment ially a power lay in tiso so

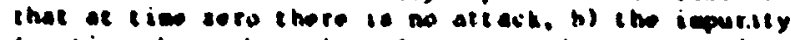
functione haw the value of untly et 0 cuncentration and aro eayplot ic to il as comicat rat iuns go to infinity. C) the aocond order polynowial in the ter perature of the enroment ial tere vill allow tor eaxieal rate st etlach tor eume temperature if as is leae than cero, and d) indicates. Oelief ther ito experieontal ercise is propurtional in nature rether than edditive. If ahuuld bo point od out that this lype of curve fil sequites the wes of nom-linear reexeceitun.

The behavisp of this teaily of idpurity functions is ind icecos in rigure 4. The value of pl io an anyaptote owih that of is ereater thel 1. and the tunction is enotonicelly increasing. Jib parbeter 2 guet bo greater than erro and and isates the ra-

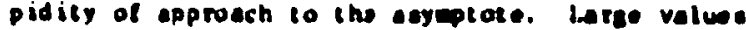
indic...e rapld epproech and enall or.luas indicate slow eppruech. If 1 se loen than I ehe turnetiun is monotonicelly decreseins tu 1 . beall valuos of 12 indirato a low eppruach and lerte value a rapid approach.

\section{RESULTS AND DIsussion}

\section{$x$-Der Diffrection of Deponite}

A. a reaule of the meny different cest cunditione on lour elloys, there is plethere of $x$-rey diffrection

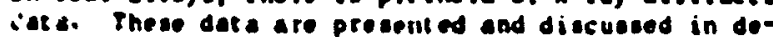
tail in the Appondix. In general, the dupants tended to fern the same types of veposise regardlese of the comientration or the combinat tons with other ele-

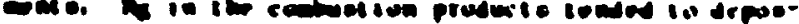

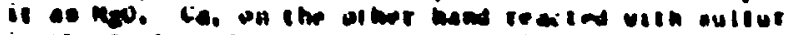

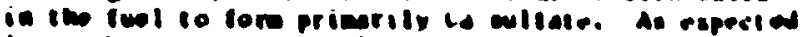

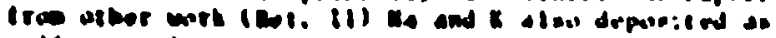

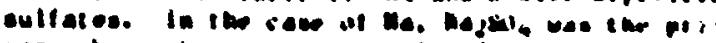

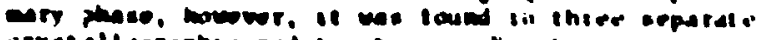

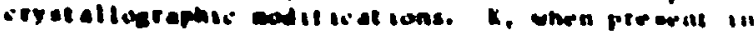

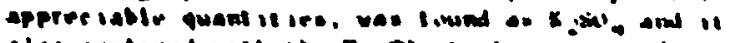

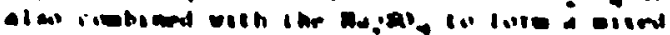

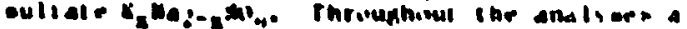

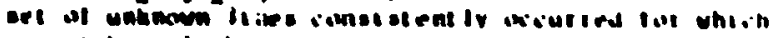

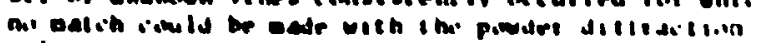

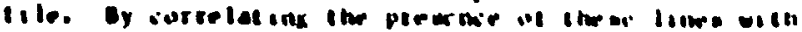

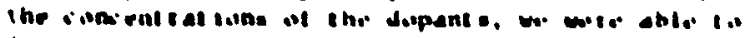
detertion that this was probubly that priedily

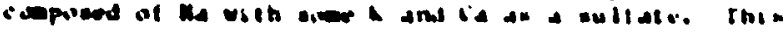

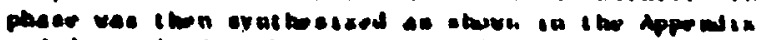

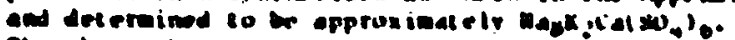

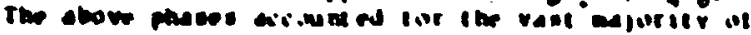

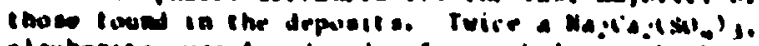

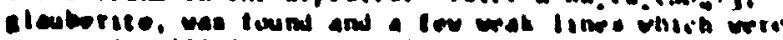

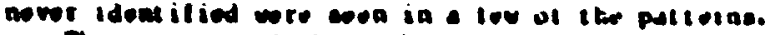

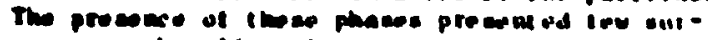

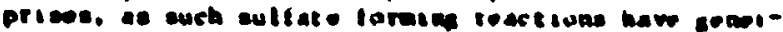

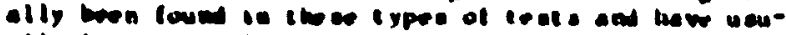

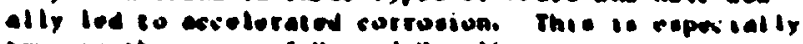
true in the canes of the and 4 celtetes and the ir ela-

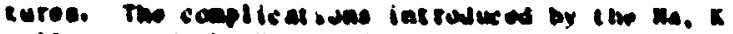

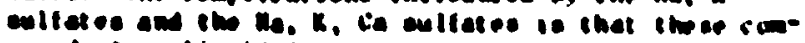

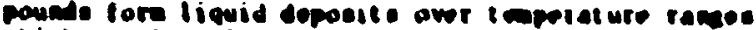

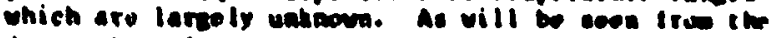

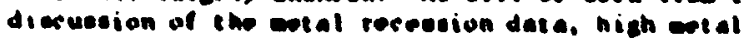
receseisns ert secociated. at would be eapected, with lerse cowent rat ione ot ha and $x$ euliates.

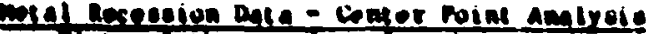

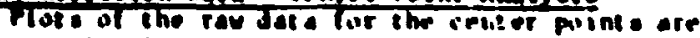

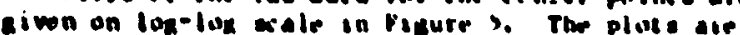
dan eoparately tor tach ride. Table IV prowerl the results of the resteseton analyas tive dach alloy.

The analyeis i: the IN-IUS senter point dat in-

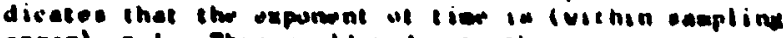
error). - 1. This would indecate the ciortovesn is procodian via a artece reacion. dush rections muld indicate ehat mo protertion laver in molng torere od during the cor soive pricess and wuld probably recult in highly accelerated currosion, al inderes

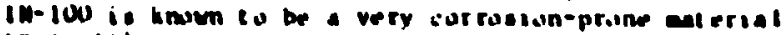
(Ret. II).

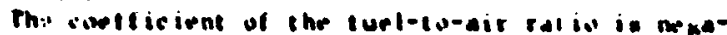

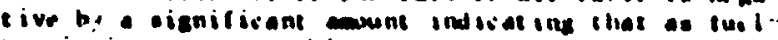

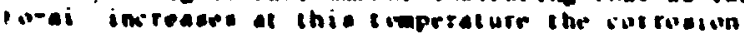
rete secrease. The te aule are not in atretent with the inel-tu-air ratio eftects upeerved wa nar

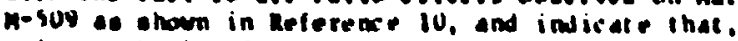
quit probably, fupl-tu-air as veriable, like sis wny of her variables as found in neference II, aftect diflerent alloys different ly.

The cuetliciente of the ris etfect inply that rige na and two ere ainiler as ere rige thres end four. but the two dete jetter eiente icant ly. This difference is apperent troe the rev data pluts of bise-

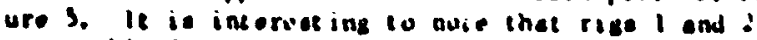
are cabined un une lable in the labural ary and and rige 1 and 4 are an anvether cable. While nowianlly

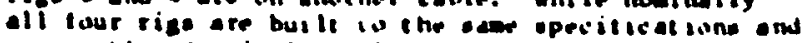
presumbly cdentival. Il is quite sbvinus from the dete that ris to ris veriat aine do exist at a level eignificent mough to be dected in this type we exporimone.

The variance and the sefandard deviatiul es inatea ere 0.0162 and 0.114 , repectively. The approximate 


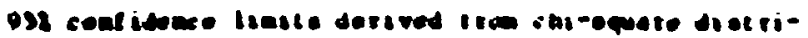

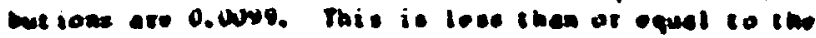

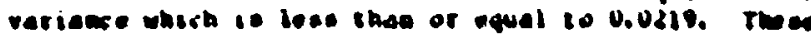

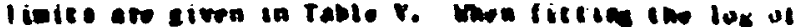

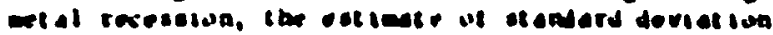

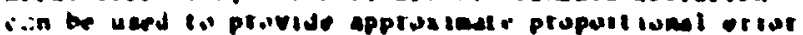

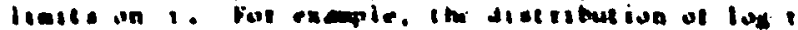

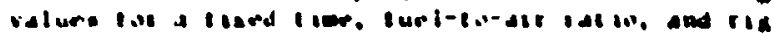

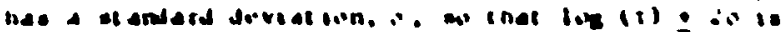

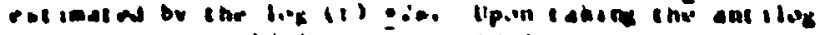

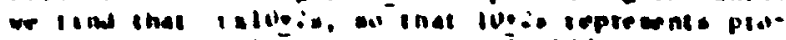

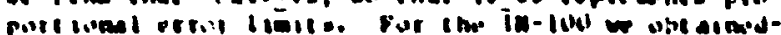

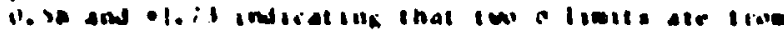

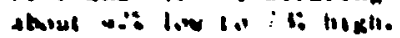

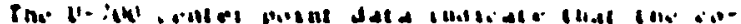

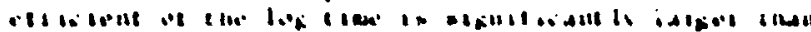

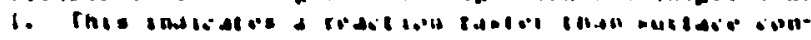

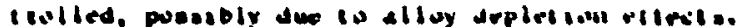

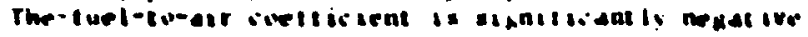

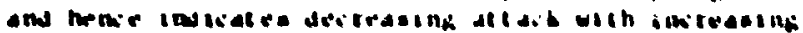

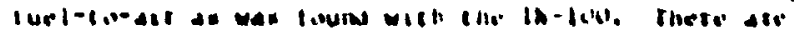

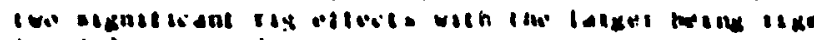

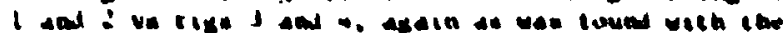

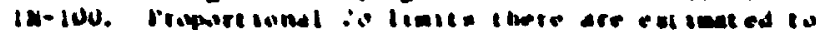
bo sus ise to lo it nigh.

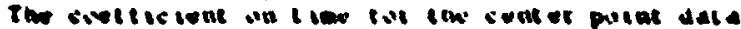

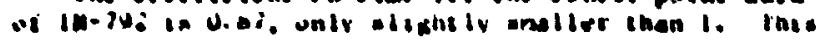

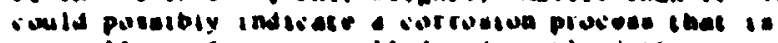

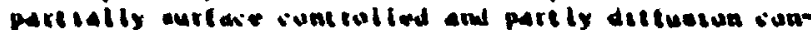

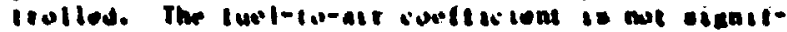

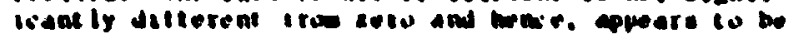

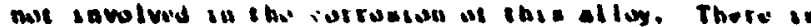

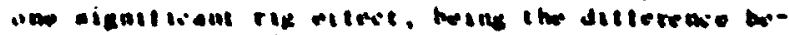

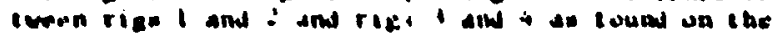

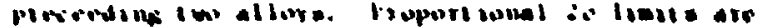

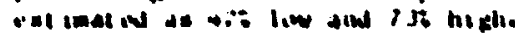

The rat h-sus center poine romilts indiceted a

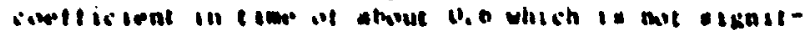

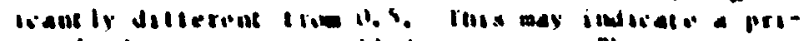

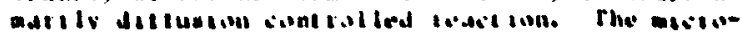

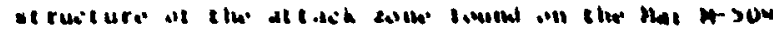

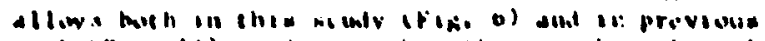

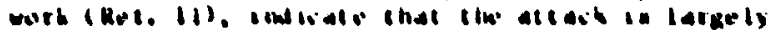

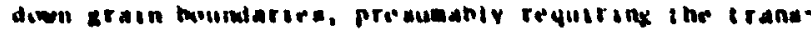

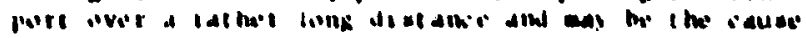

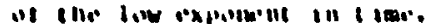

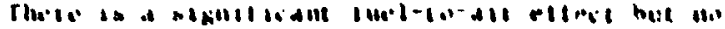

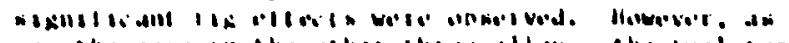

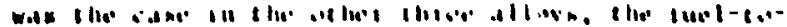

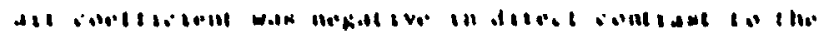

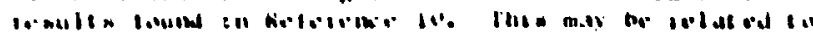

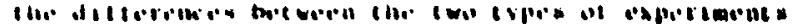

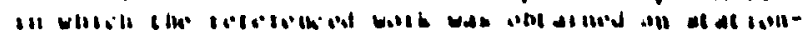

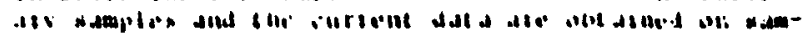

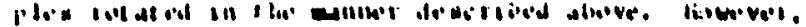

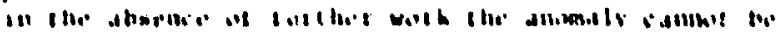

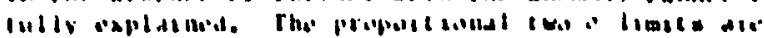

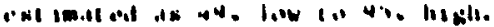

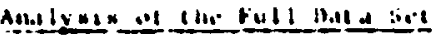

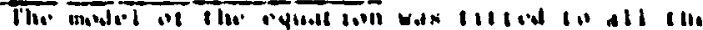

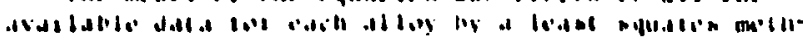

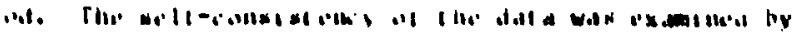

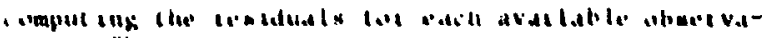

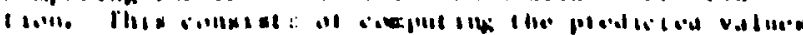

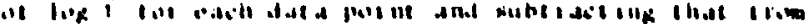

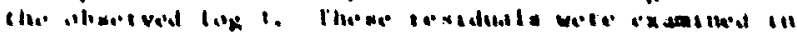

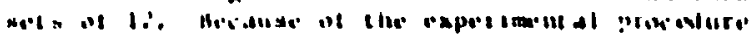

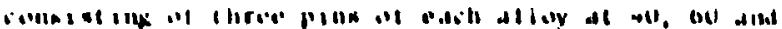

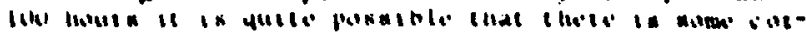

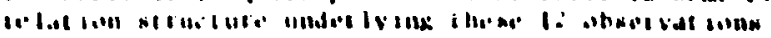

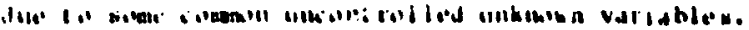

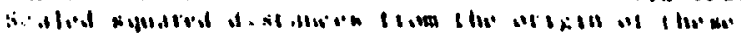

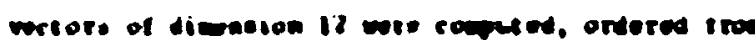
the wellest to the larges, and plated en e ehi-

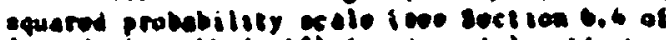

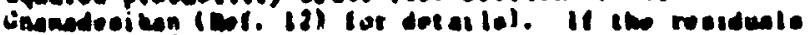

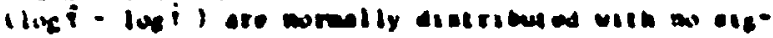

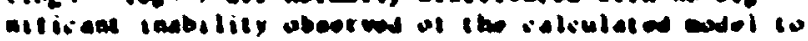

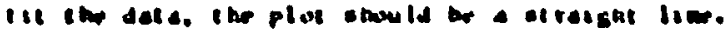

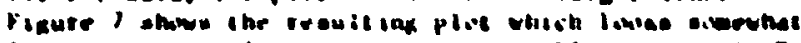

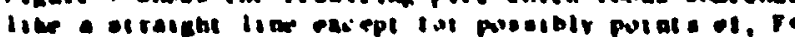

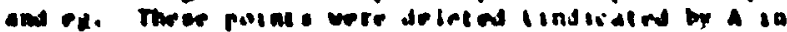

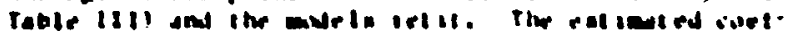

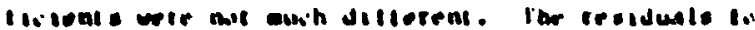
inis tie wre salicilated and platerd vith the iesule

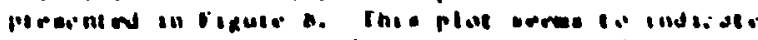

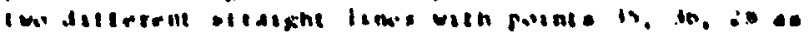

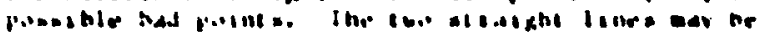

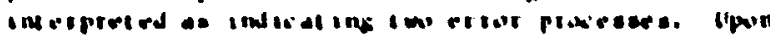

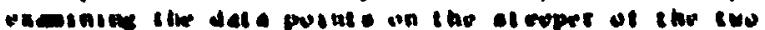

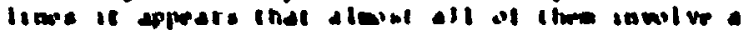

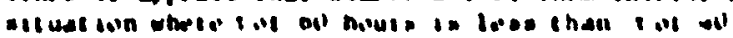

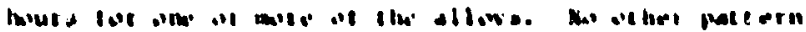

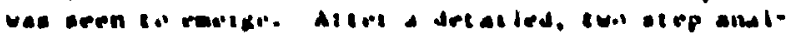

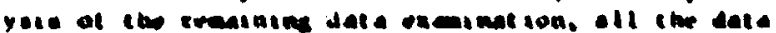

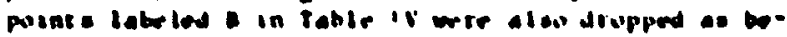

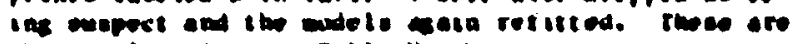
the recule sivon in Table V. Upion simparion is wes - noted inat in latee ditterence is in ibe exi-

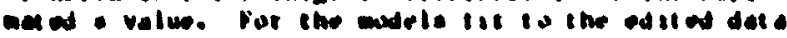

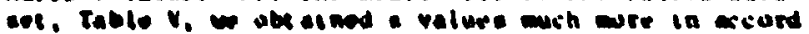

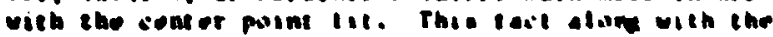
litiod ecmations wing guito siatlar lar all thice

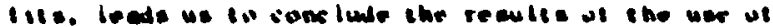

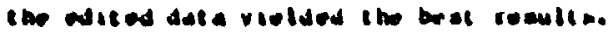

\section{Expre}

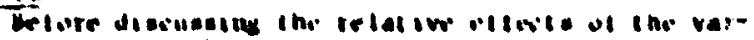
iables on rach elloy, the ret imat of ut in realdual

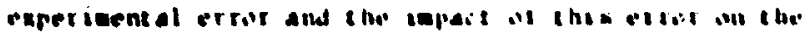

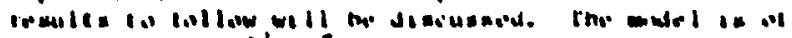

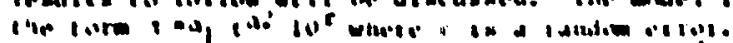

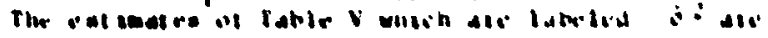

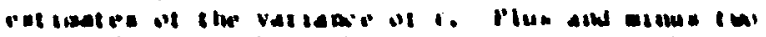

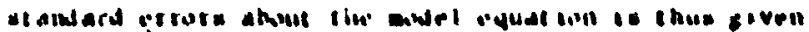

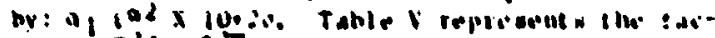

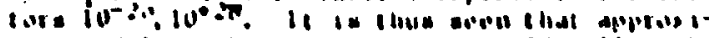

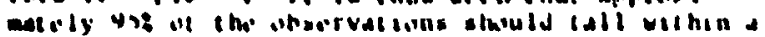

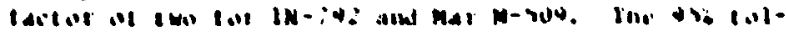

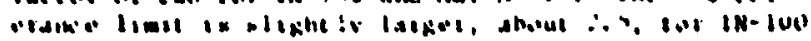

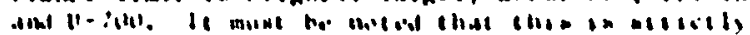

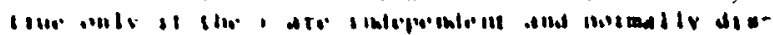

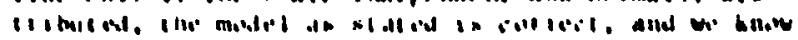

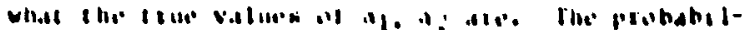

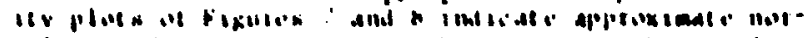

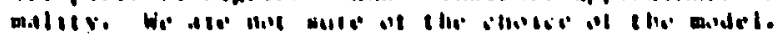

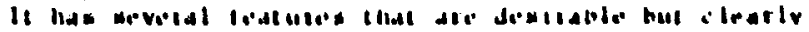

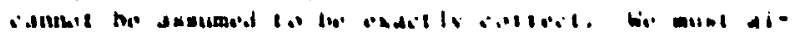

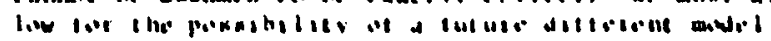

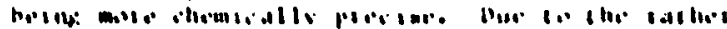

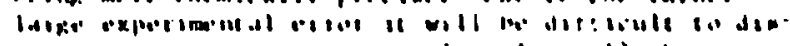

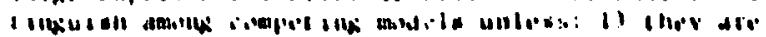

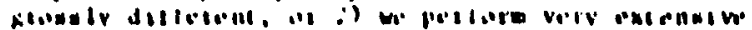

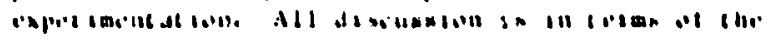

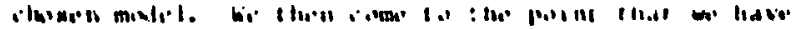

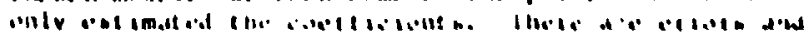

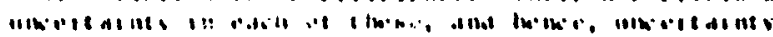

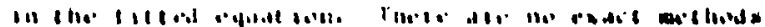

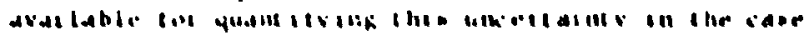

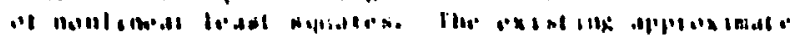

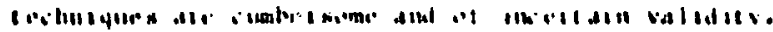

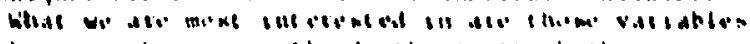

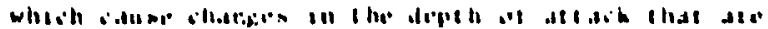

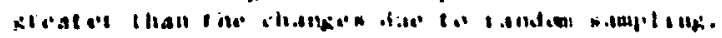


2010

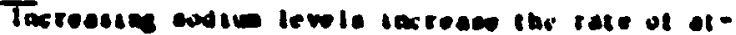

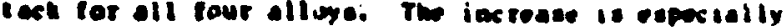

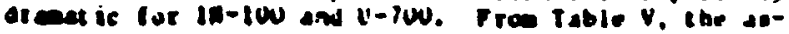

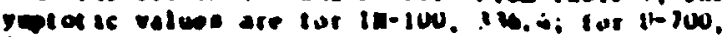

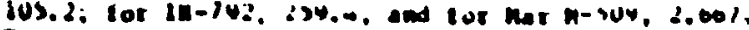

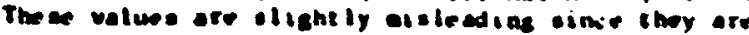

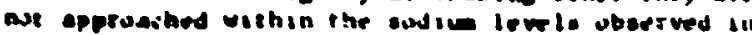
the oxperiesen. Parpi for har $\boldsymbol{w}$-s09. Figute glal

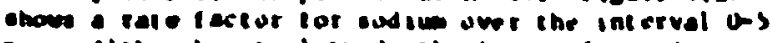

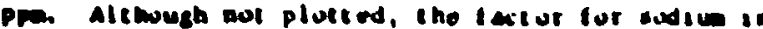

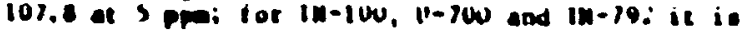
- vident thet ine change in ate act over itur us ppo rance is consoderably larker that the experserntal ercor. While $10 x$ ner n-jus the chenge as cluar to the erme linile. There ere evidenty real ditereace

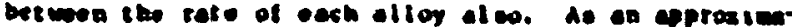
cion consiter that at 2 ppo the predicted fectore and the ertror lieics ore

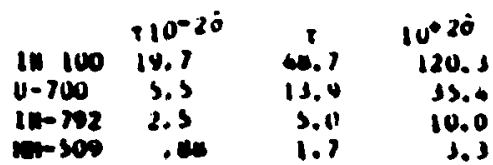

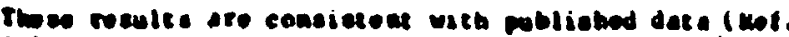

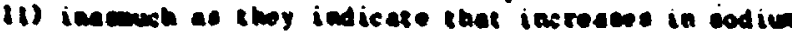
ar - cwer of increasin atcech. and that the ellope corrode in approsimetely the onder ow would onget.

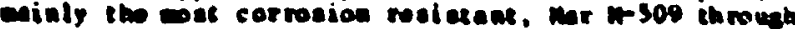
tho leat corrosion resiatan. In-100.

\section{Parasic.}

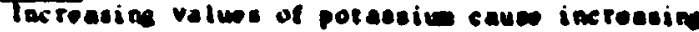

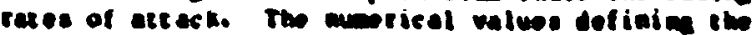
race fuxction are given in Table $y$, and the function ploted ower $0-5$ ppe in Figure $q(b)$. The change in Ch owr that rage is clearly lareer than the randon errar efferts. but apreare to he abnut the seme for ach alloy.

\section{Menceice}

Increacing agnesiu concentrat lone dectrace at tack for all but ine Mar N-S0s alloy. The mar $*-509$ alloy indicated onentially no fifat wver the ranes ploced, 0-5 Ppe. While tor the other alluye the chenge in at tack is ebout tho sese. Thus, tbis otudy

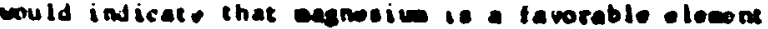
a would be copiciudad from neference 13, but not eopecially oo. The behavior of In-100 and in-792 are very wach alike. These resules are ploted in Figure g(e).

\section{Calcin}

Calcium appeare to be a favorable addieive an increasing calcion conceat ration leads to decrenciug attect for ell alluye. The nuerical values in rable $\checkmark$ indicate rate reductions of tru 0.195 to 0.607 . These lieste are mearly achiews vithin the lovele of calcium exanined and the tactors are ploted frou u-J pow in Tigure $Y(d)$. For $I N-100$ and $1 M-792$ chere is very rapid reduction in rate, uhi le for $U-700$ and for Ma- M-soy reduction is not do rapid. Over the range of 0-S ppo the change in the funciton is lerrer than the ertor limise. These data are certainly consisent with the inhibitor deta published in tieference 13 , which found shat calciu decteased corrovion to sue degrea.

\section{Chlorin}

Chlorim eleo appeare to bo bemficial dopert.

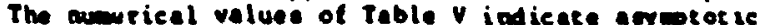

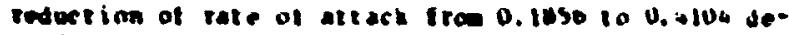
poedia upon the alloy. Ihlorim cancentativus lape

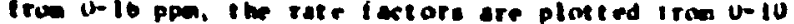

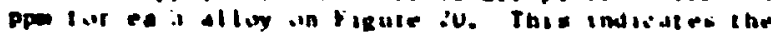

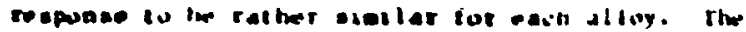

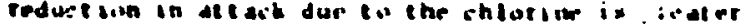

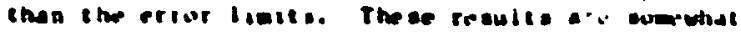

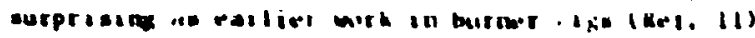

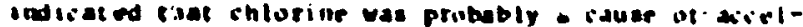

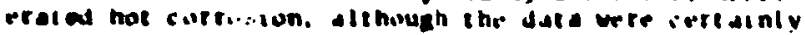

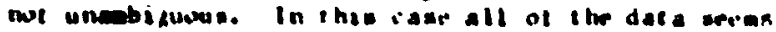
in at rong iv indicate that chlocine, whent present. can be a cause of rodust bun wi hut esr rasesun and nat il

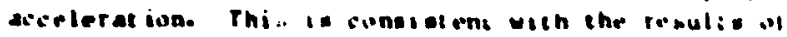
sareril ( Het. It).

nire

(he inpertan and sialurbin veriable to consider is rite efiects. :he rige aro monealiy identical. thus what ever vat ability there is true une rix to ariother is a lowe bund on the ditiprences that could roule boves im different labe. This to hocaus

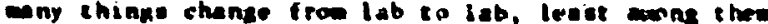

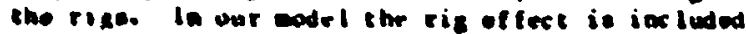
through the inclution of the two dumy vuriablea, al and $R_{2}$. Toble $V$ presente the deviat son of ech riz Irom a monal or coan ris by indicating the value of $10 m\left(a_{1}+n_{2}+n_{1} n_{2}\right)$, It is thus ceen that

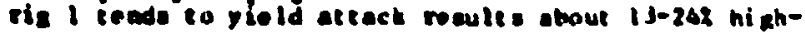
or then acielel. uhile rit 4 yielde rosult sbout

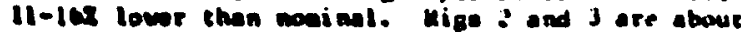
awrace In their eftect on corrusion at tech.

\section{Toceresure}

The eodel chocen for the cenperature rate factor

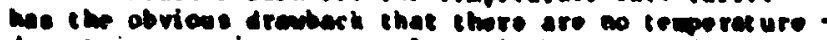
dopant intoraction tetre. It vould be enpected that He could nut how an interaction effect over the rates of ine orost. It iore na which prubably ecto only se -ither an inert colid or a a diube inhibitor (Dof. 13). Monewer. Mro is solid at all teat tempera-

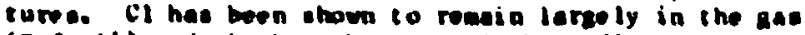
(a)f. Is) abe vhother there chould be (1 - imperath: inserection is qupationbble. (he wuld expect Wa-, K-, and Ca-temperature interactions as the tur aulfate whose dey pointe and citine pointe any be in the coat temporature range. Since it a enerally aseunod thet eccelerated cormeion necurs prierily at toperatures wetwen the beltin point and the dew point of the deposits, the compusitiun of the deposit should efronaly int luence the shape of the temperature - corrovion curw.

At this ot age of the developent these types of interectione have not ben included in the nojel. Mevertheleso. the temperature profiles predicted by the model are in reaconoble agresennt with the obwerved date which wold indicate that the potens ial interaction ceme are not necestarily firet onder pffecte owe the teperature rare of int rest here. rusther refinments in the nodel any include the eaperature-dopant ine eract iun ceres provided that this effects are greater that the uncertainty in the data.

\section{CONLWDING REMARs}

An atempt hat been made to atudy the corronion atceck of turbine airfoil elloys a a function of tia, $\mathrm{K}, \mathrm{Ce}, \mathrm{M}$, $\mathrm{Cl}$, rmperature, and time urilizinu atetieticelly designed burnes ris proste. An atteck nodel was deviloped from these resules which, while obviouly imcoplete, scems to sccount for mot of the 


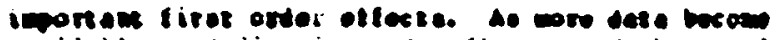
availeble, odefication an tefinom of the eat should allue ereater pralictive abilisy.

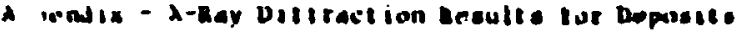 by relph b. ierlich}

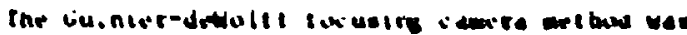

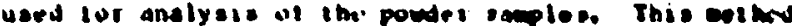

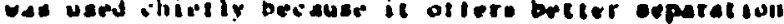
"I peak. than the wher ivartatie mothody in the rale"

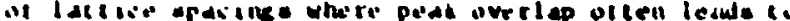

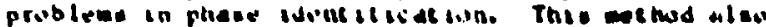

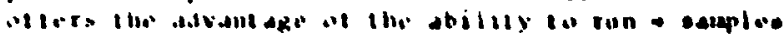

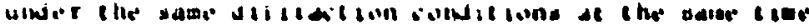

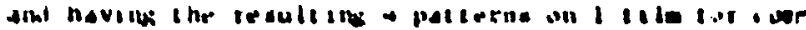

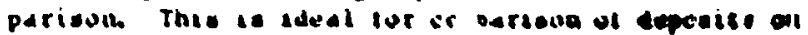

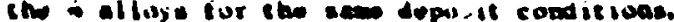

The resulte ol the ditisation analyses are sue adiled in Table lit. Under edith phaur the letedere

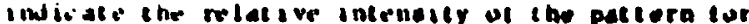

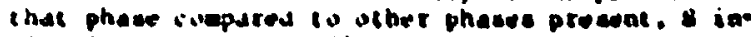
dicte ing strong, N opdiue, and wat. Tho ceaser

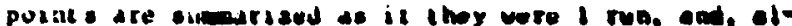

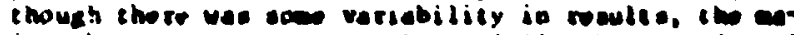

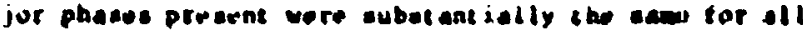

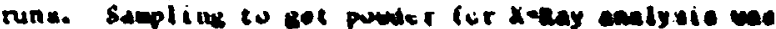
Jore primerily for annlysis of the depuited esterial

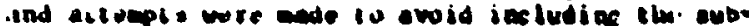

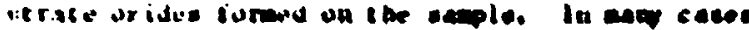

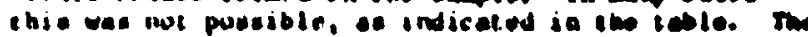

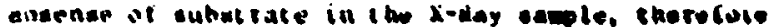
dive not indicele that mas vas preent on the che

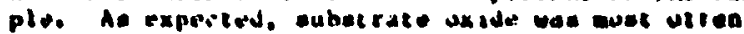

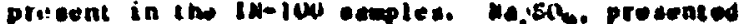

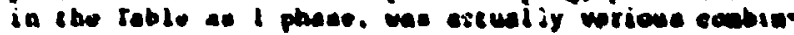

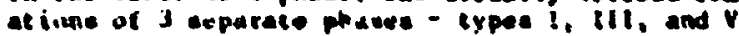

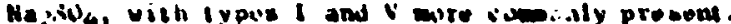

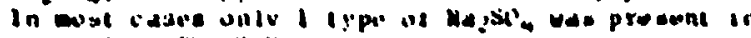

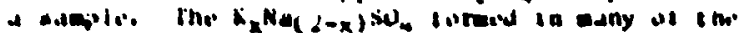

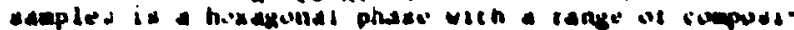

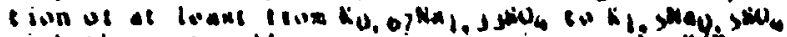

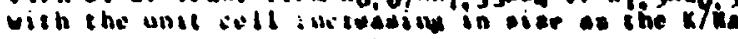

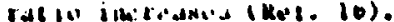

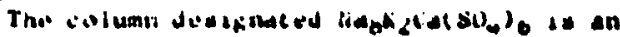

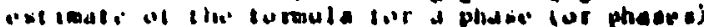

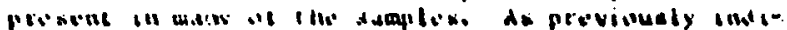

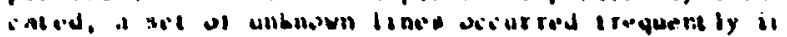

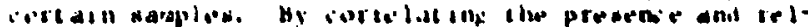

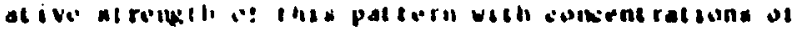

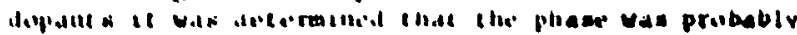

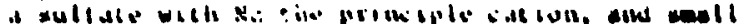

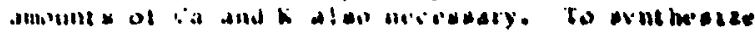

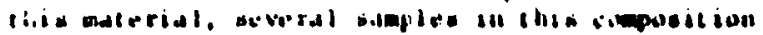

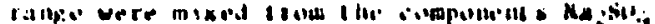

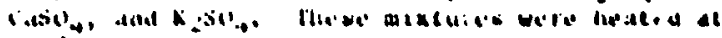

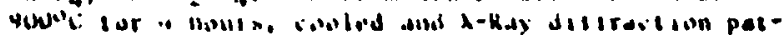

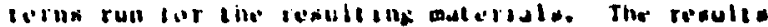

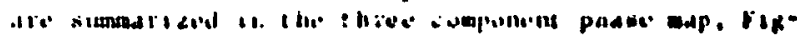

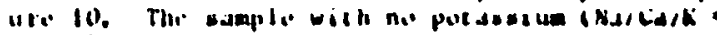

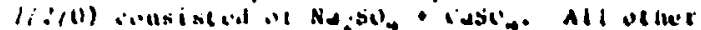

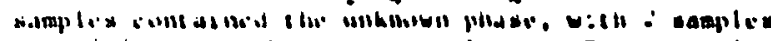

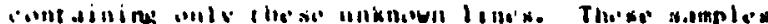

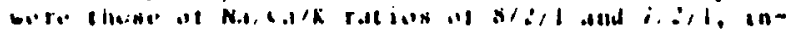

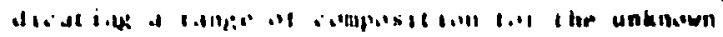

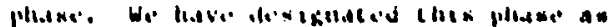

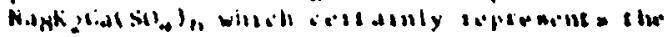

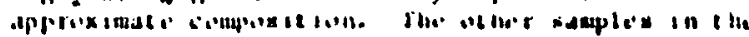

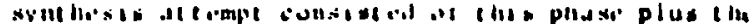

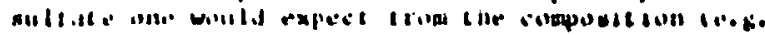

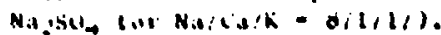

\section{erouncy}

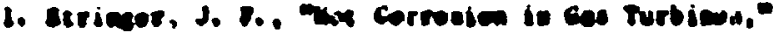

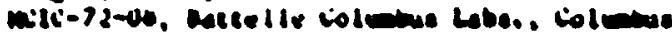
Uhis. Juen ivid.

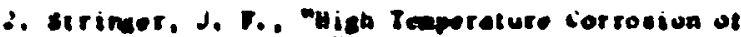

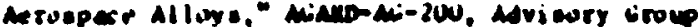

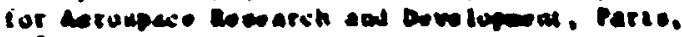
isis.

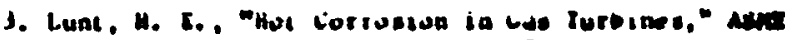
Paper an. Il-us/Yu-s, Muv, Iy7z.

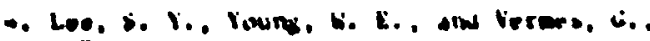

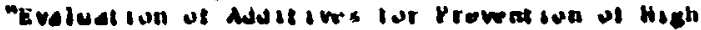
Tmporature iutruasun of superalluye to bes

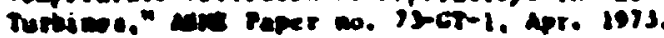

3. Letlerid, M. J., Mav, H. R., aw Akmund, R. M.

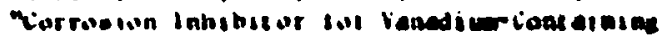

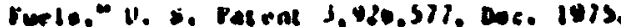

- Low Il, C. E. and Dectare. O. L. Mitfees of

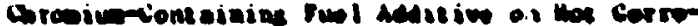

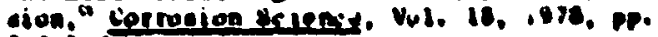
$76 \% 703$.

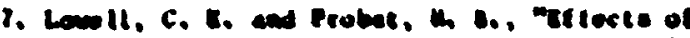

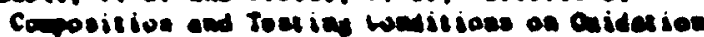

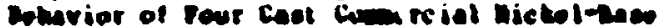
emeralioy " " man Th D-770s. 1076.

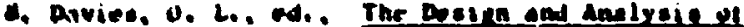

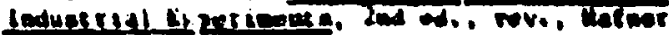
Hot, va.. inu vork. Tise.

9. Wur, C. I. P., Hunt er, H. i., and tuat et, J. S.

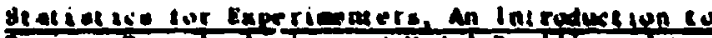

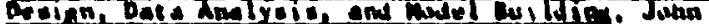
Wiley and sons, ine Tork, Fis,

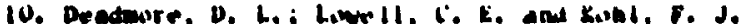

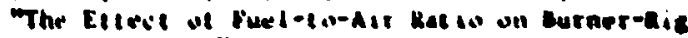

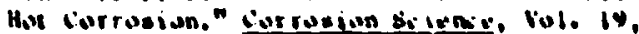
1474. $\mathrm{pl}, 111=37$.

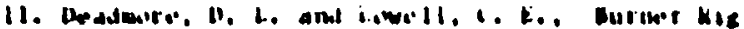

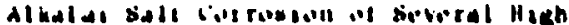
Tompraluse Alloys," Masd he A-i mov, 19i.

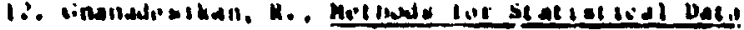

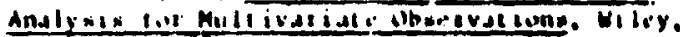

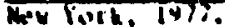

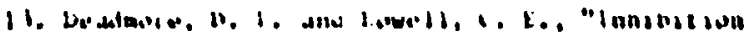

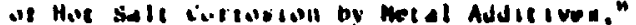

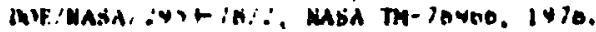

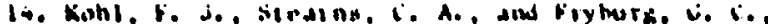

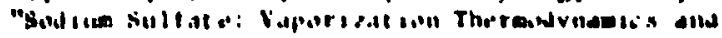

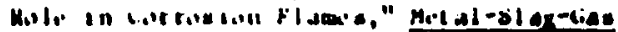

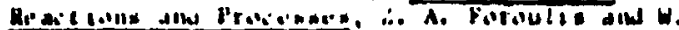

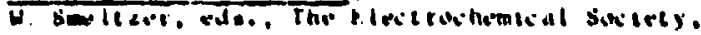

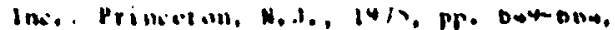

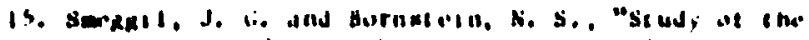

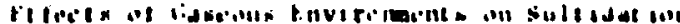

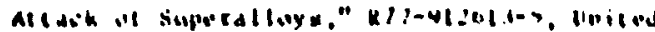

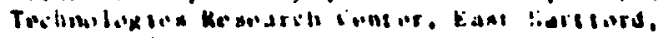

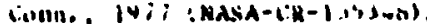


TADLE 1. - Comosition of allots

(All velues are wolghe porcons)

\begin{tabular}{|c|c|c|c|c|}
\hline ereanr & $10 \cdot 100$ & 0.780 & $11 \mathrm{n}-192$ & min-50s \\
\hline Cr & 10 & 14.2 & 12.7 & 23 \\
\hline $\mathbf{m i}$ & ens, & Eat. & mal. & 10 \\
\hline co & 18 & 13.3 & 9.0 & nel. \\
\hline $\boldsymbol{A l}$ & 3.5 & 4.2 & 3.2 & . \\
\hline$T i$ & 4.7 & 3.3 & 4.2 & 0.2 \\
\hline mo & 3.0 & 4.4 & 2.0 & . \\
\hline " & - & - & 3.9 & 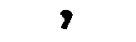 \\
\hline TO & - & $=$ & 3.0 & 3.5 \\
\hline mo & - & . & 0.9 & • \\
\hline$r$ & 1.0 & . & . & - \\
\hline$m$ & - & $<.01$ & . & . \\
\hline 10 & • & 0.1 & • & • \\
\hline 81 & • & $<0.1$ & - & • \\
\hline $2 \pi$ & 0.6 & $<.01$ & 0.10 & 0.3 \\
\hline D & 011 & 0.02 & 0.02 & • \\
\hline c & 0.18 & 0.06 & 0.: & 0.6 \\
\hline
\end{tabular}

TABI. I. - THF SETEK INITIAL VARIAGLES AND THEIR LEIELS

star (-)

.o4 PrM

A Nac:1

A Nand

: Ni:1

n $a_{2}$ sud

I: Mgt:1:

f raci:

(i TEMP
Iube $1 \cdot 1$

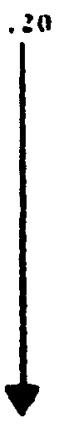

$800^{\circ} \mathrm{C}$

900
Center
Point

Cuhe $(\bullet)$

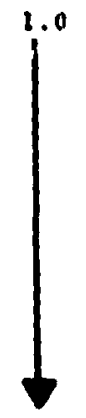

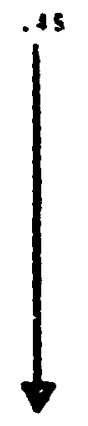

950
Star $(+1$

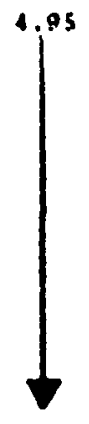

1100 


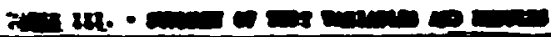

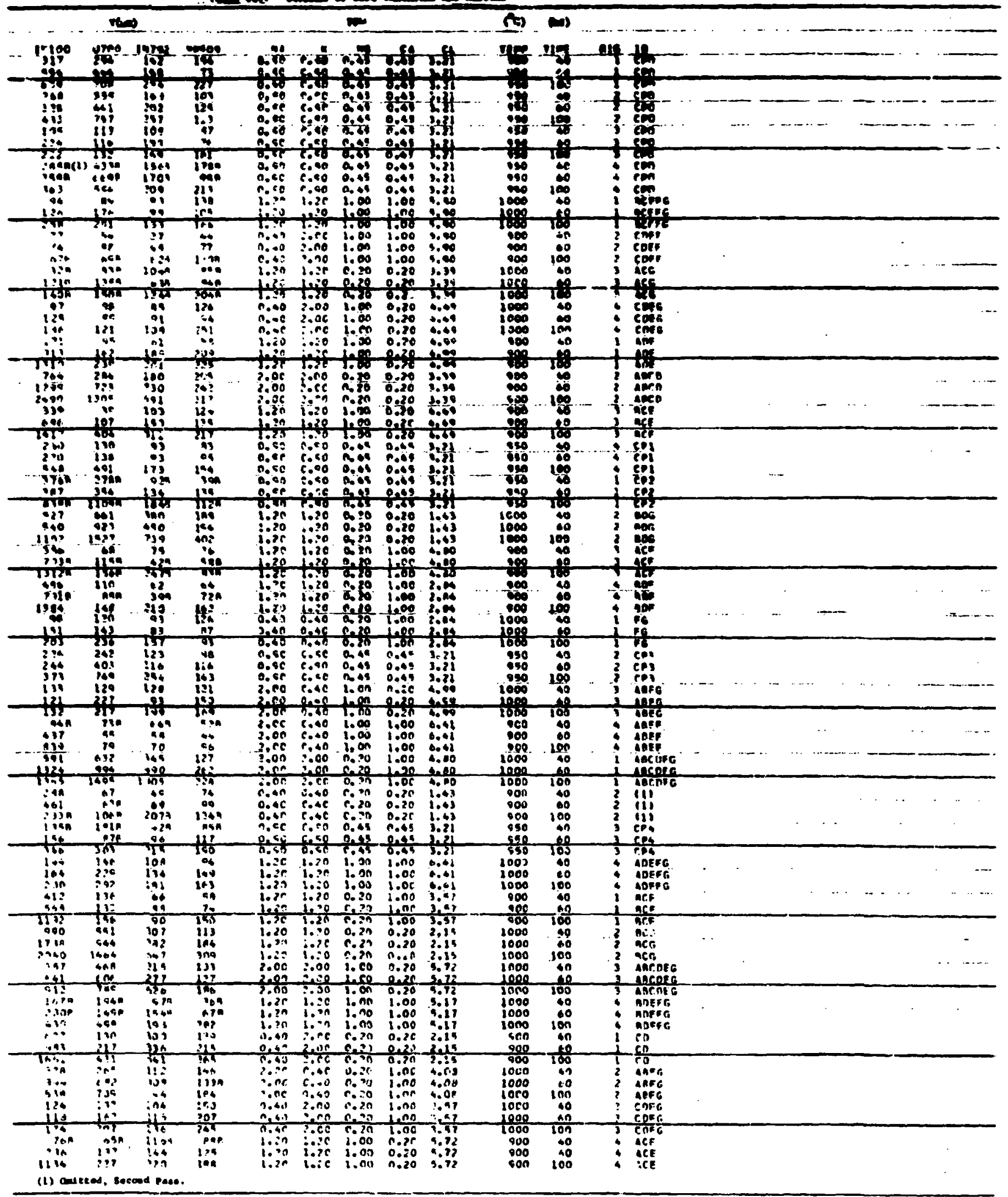




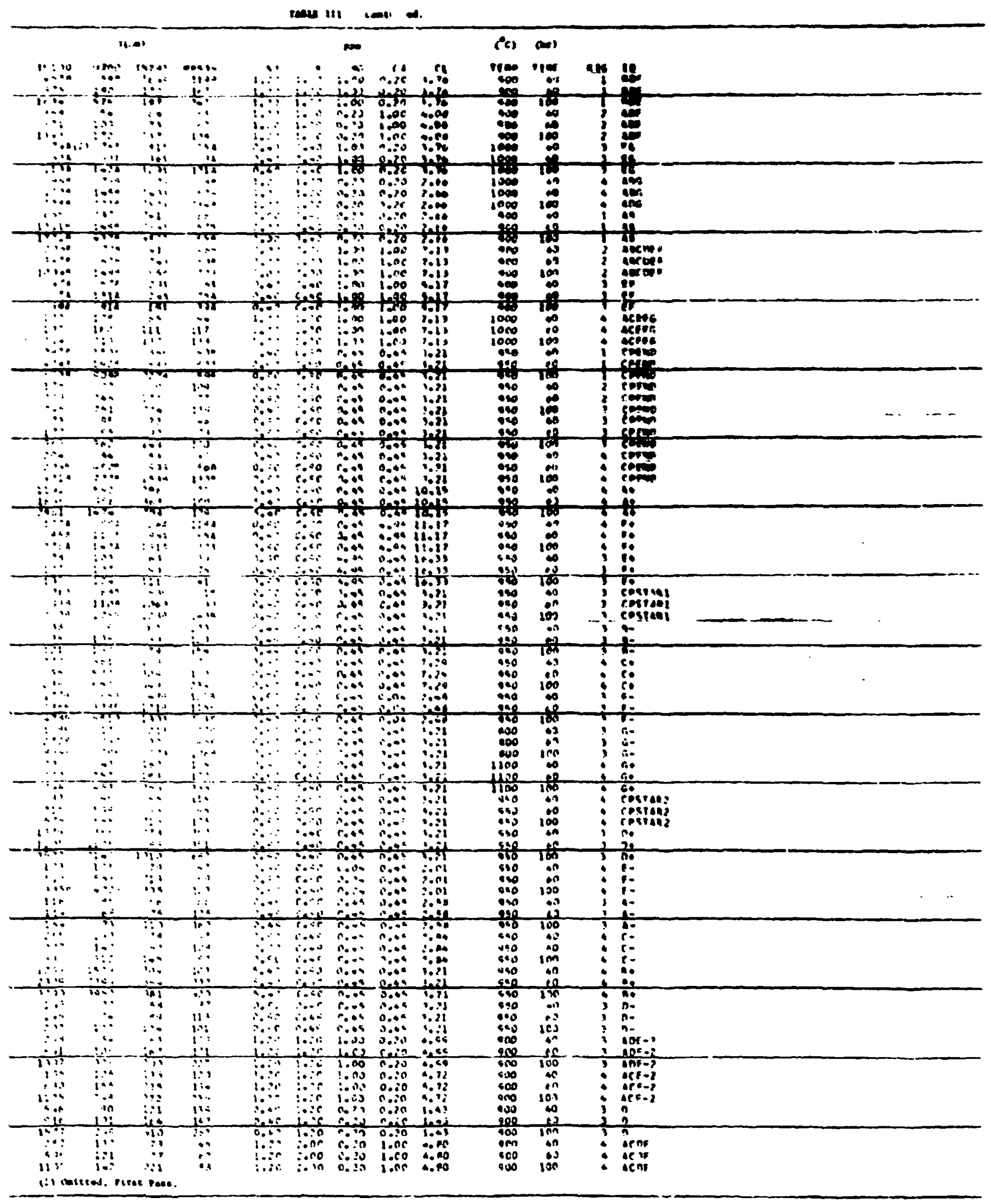


trax 411. - Conlon.

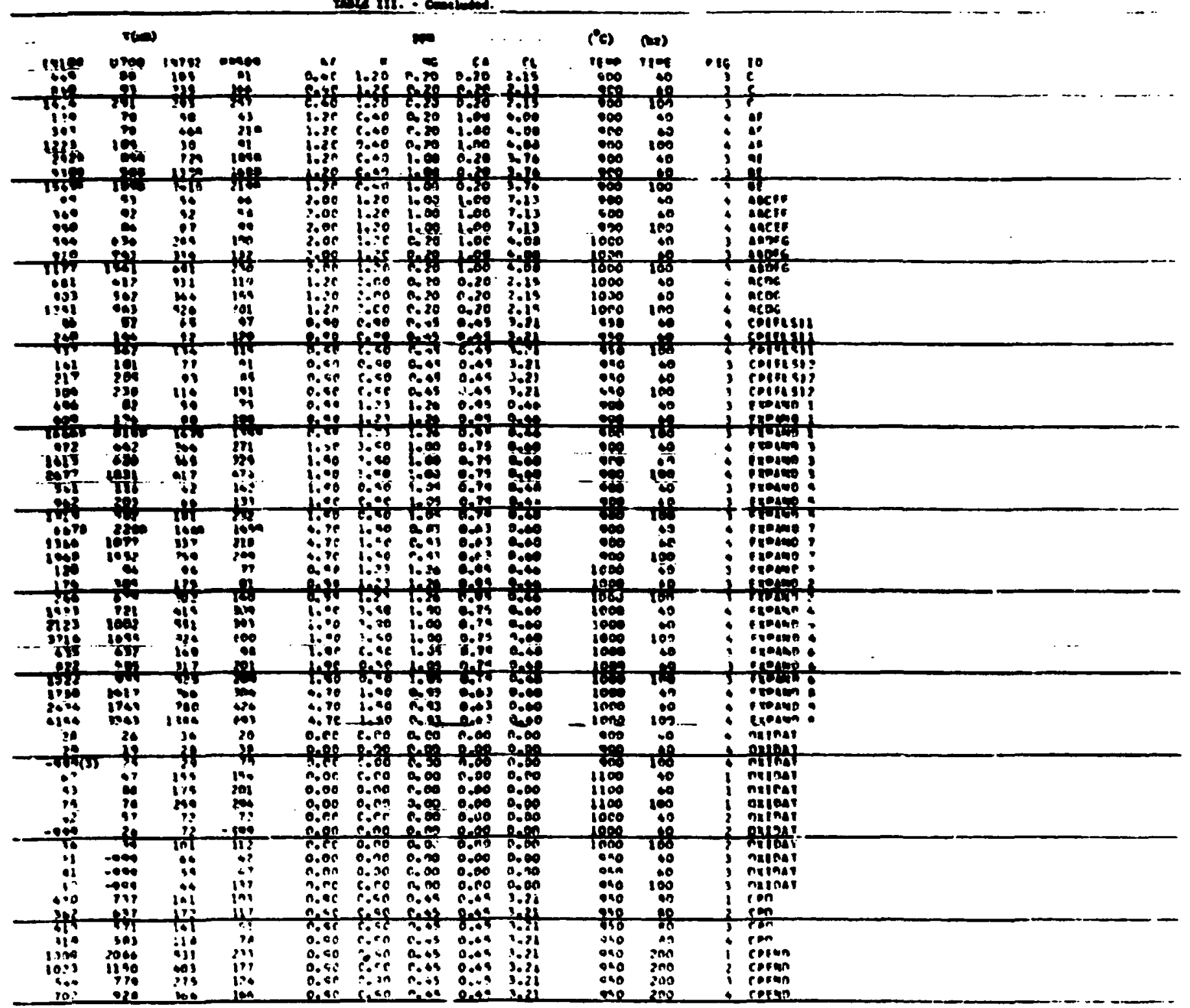

(1) adiced, mention t 


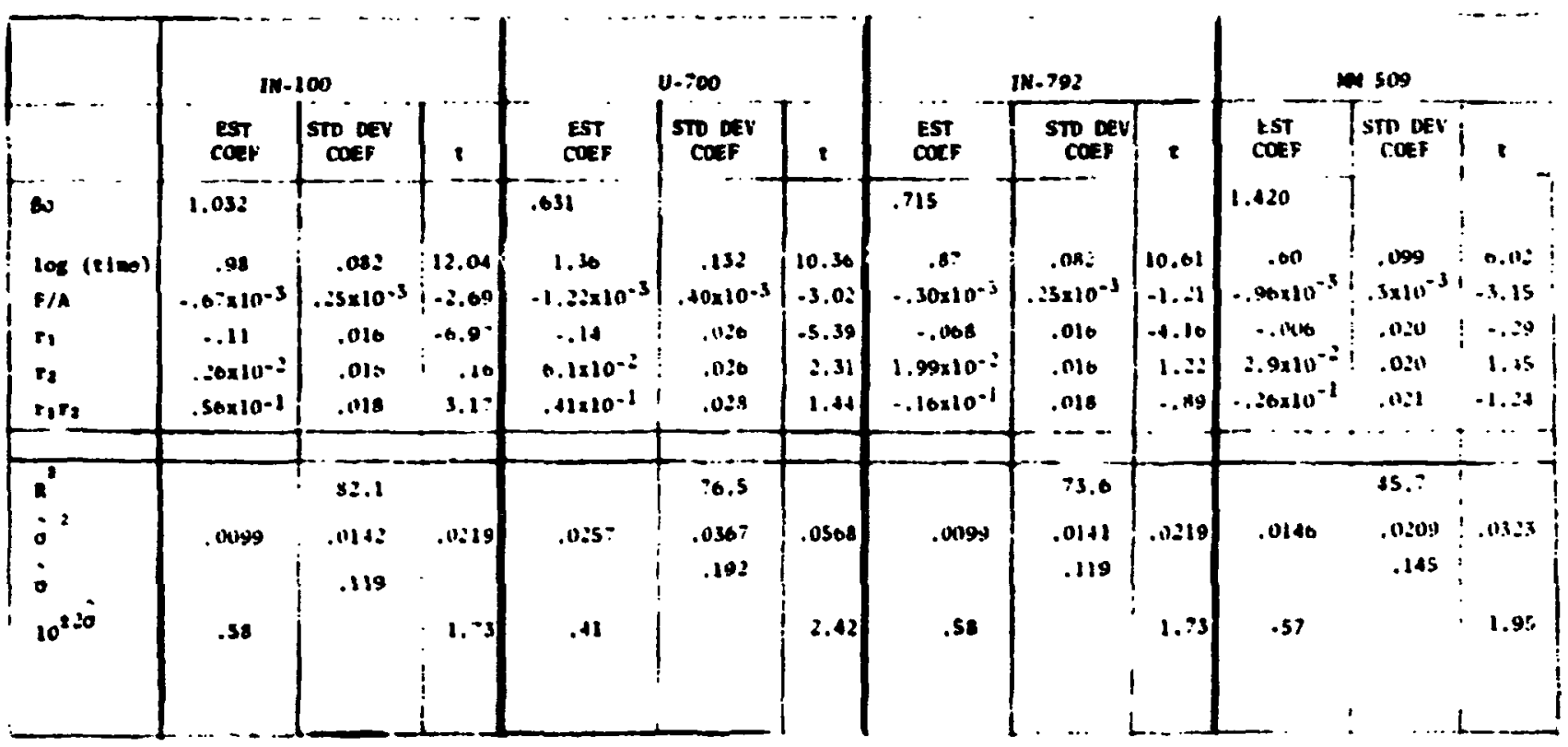

TABLE V. - RESUlts OF mODEL FITTED BY DNOPPINO POINSB LADELED (A; AND (b) IN TABLE III

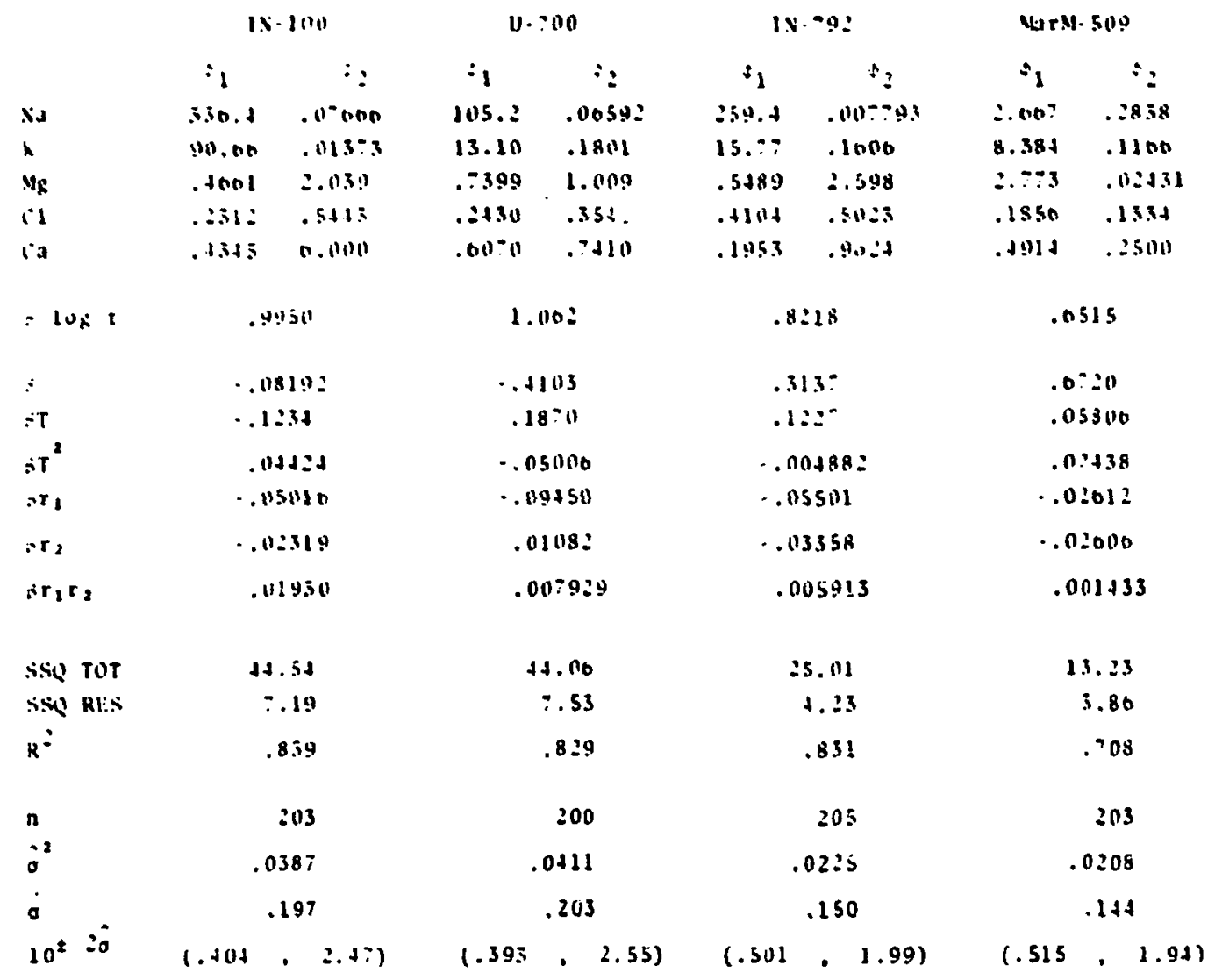




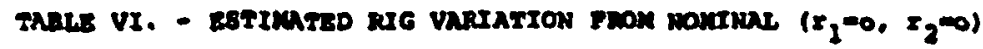

\begin{tabular}{|c|c|c|c|c|c|c|}
\hline \multicolumn{2}{|c|}{$\begin{array}{l}\text { Duney } \\
\text { vertabies }\end{array}$} & \multirow[t]{2}{*}{$\begin{array}{l}\text { Kig } \\
\text { No. }\end{array}$} & \multicolumn{4}{|c|}{$20^{B r_{1}}+B r_{2}+B r_{1} r_{2}$} \\
\hline$r_{1}$ & $r_{2}$ & & $I N \cdot J 00$ & v-200 & IN-782 & mos 509 \\
\hline-1 & -1 & 1 & 1.24 & 1.23 & 2.24 & 2.23 \\
\hline-1 & +1 & 2 & 1.02 & 1.25 & 1.04 & 1,00 \\
\hline 11 & -1 & 3 & .90 & 97 & .94 & 1.00 \\
\hline+1 & +1 & 4 & .88 & .84 & .83 & .89 \\
\hline
\end{tabular}


ThBLE $\because 11$. - PHASES PRESPNT IN DEPOSITS

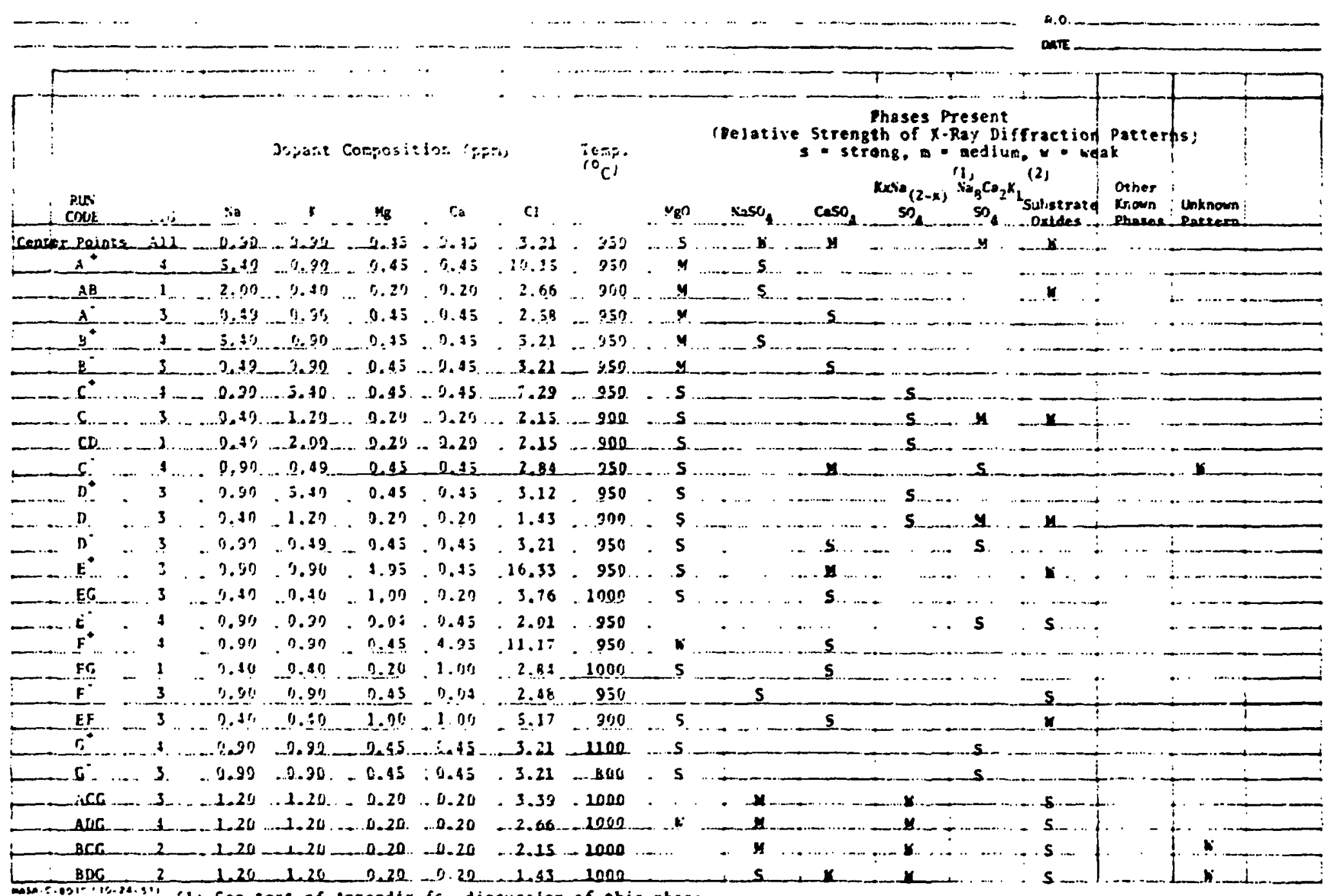

1) See tex: of appendix fc. discussion of this phase.

12j Substrate oxides usually strongest on $1 x-10 j$ samples. 
InBLe v11. - contisad.

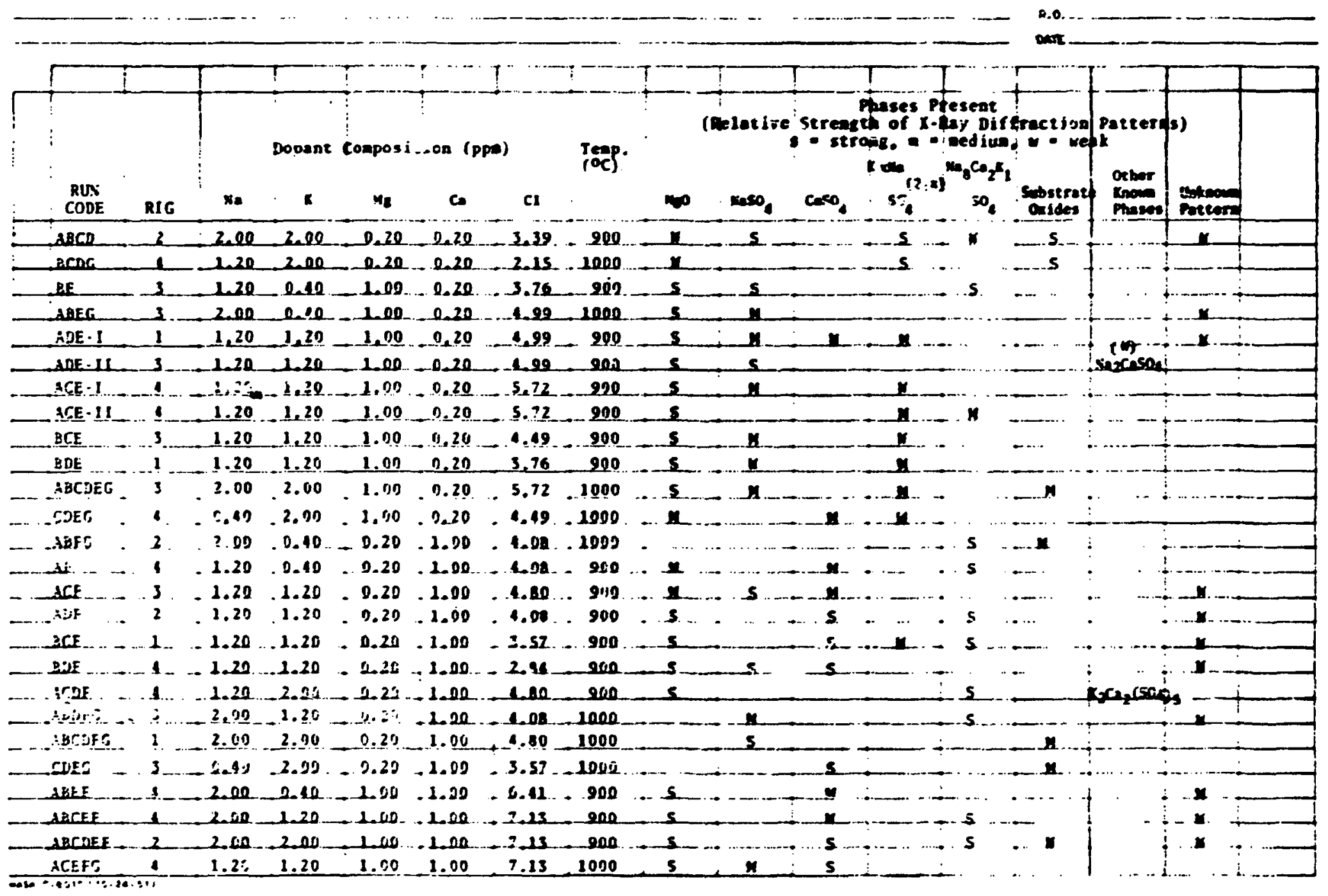


IAOLE VII. - concloded.

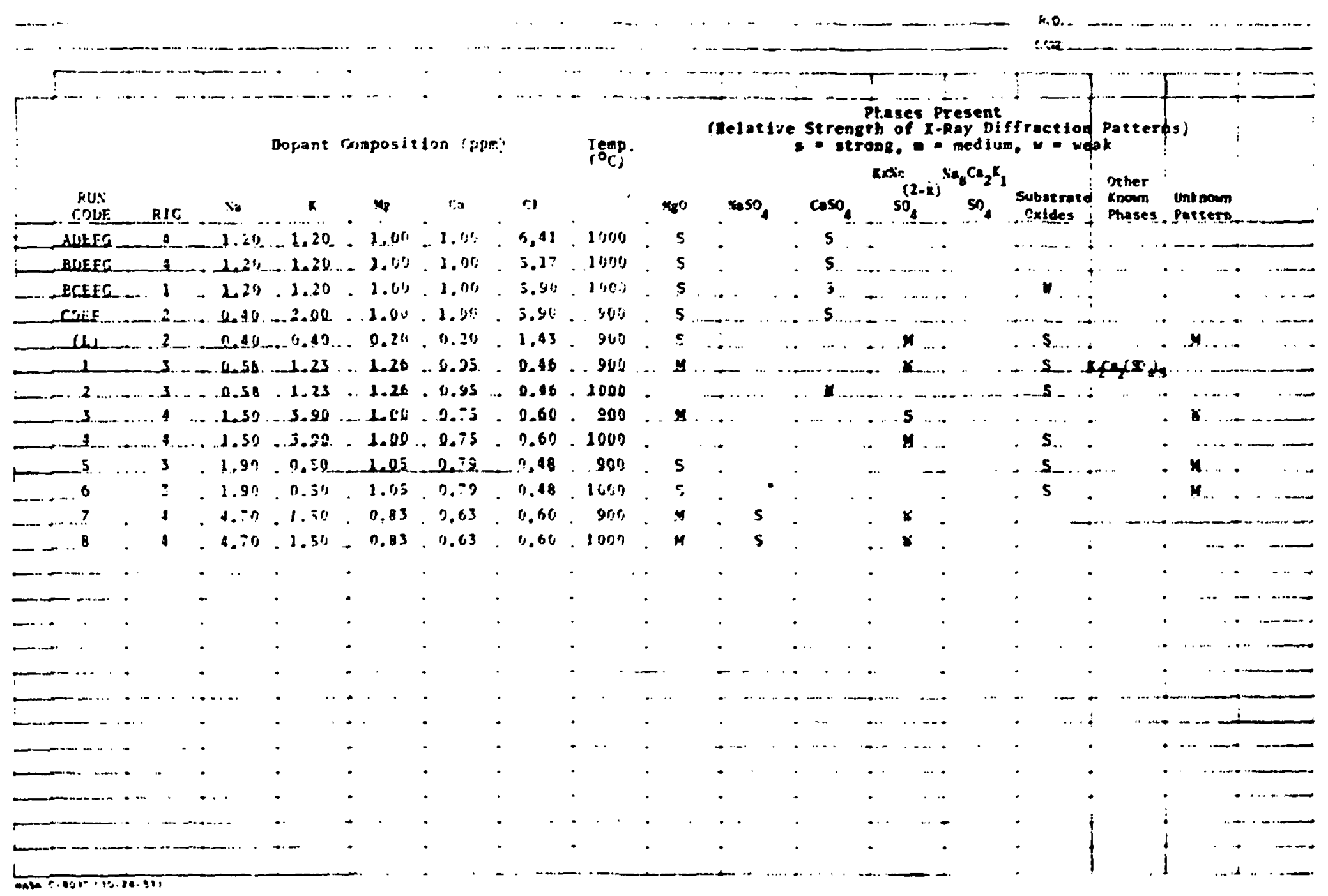




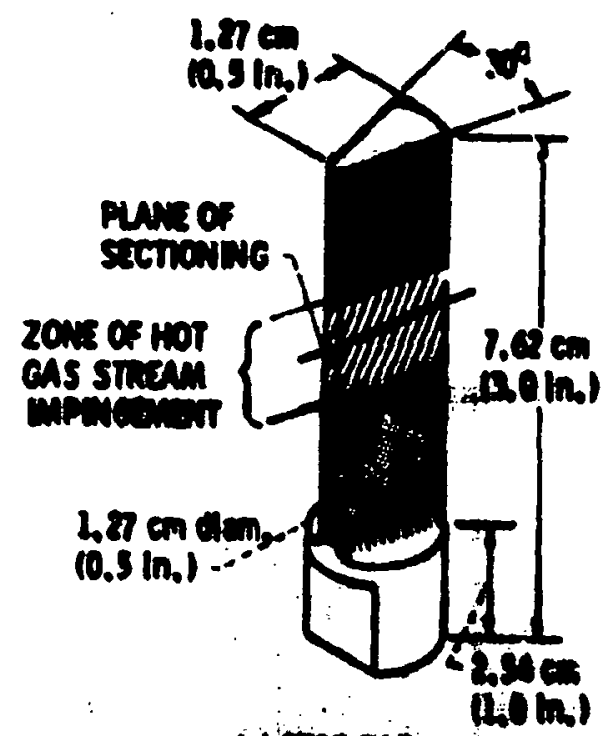

doter an

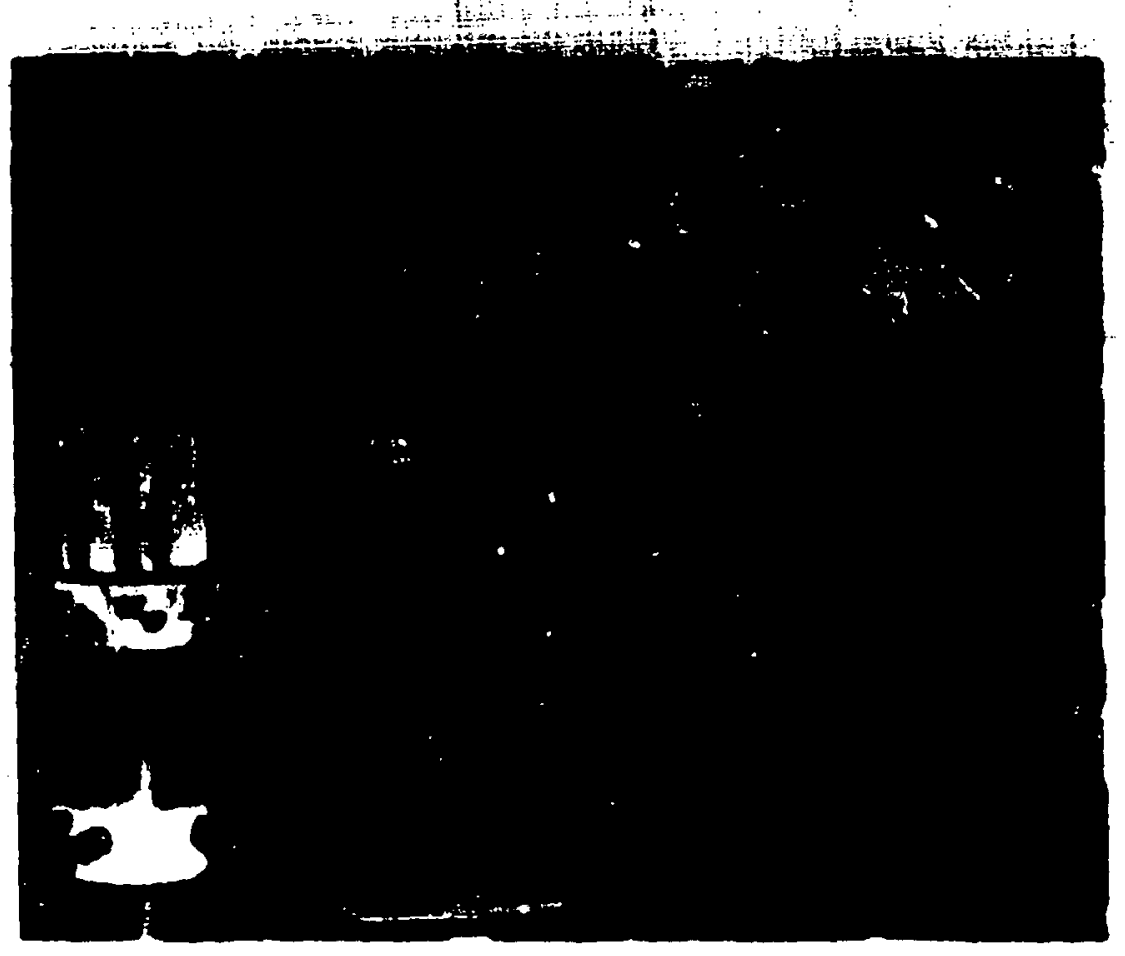

(6) Butwar RIG.

Figure 1. - Hot-corrosion apparatus and test specimen. 


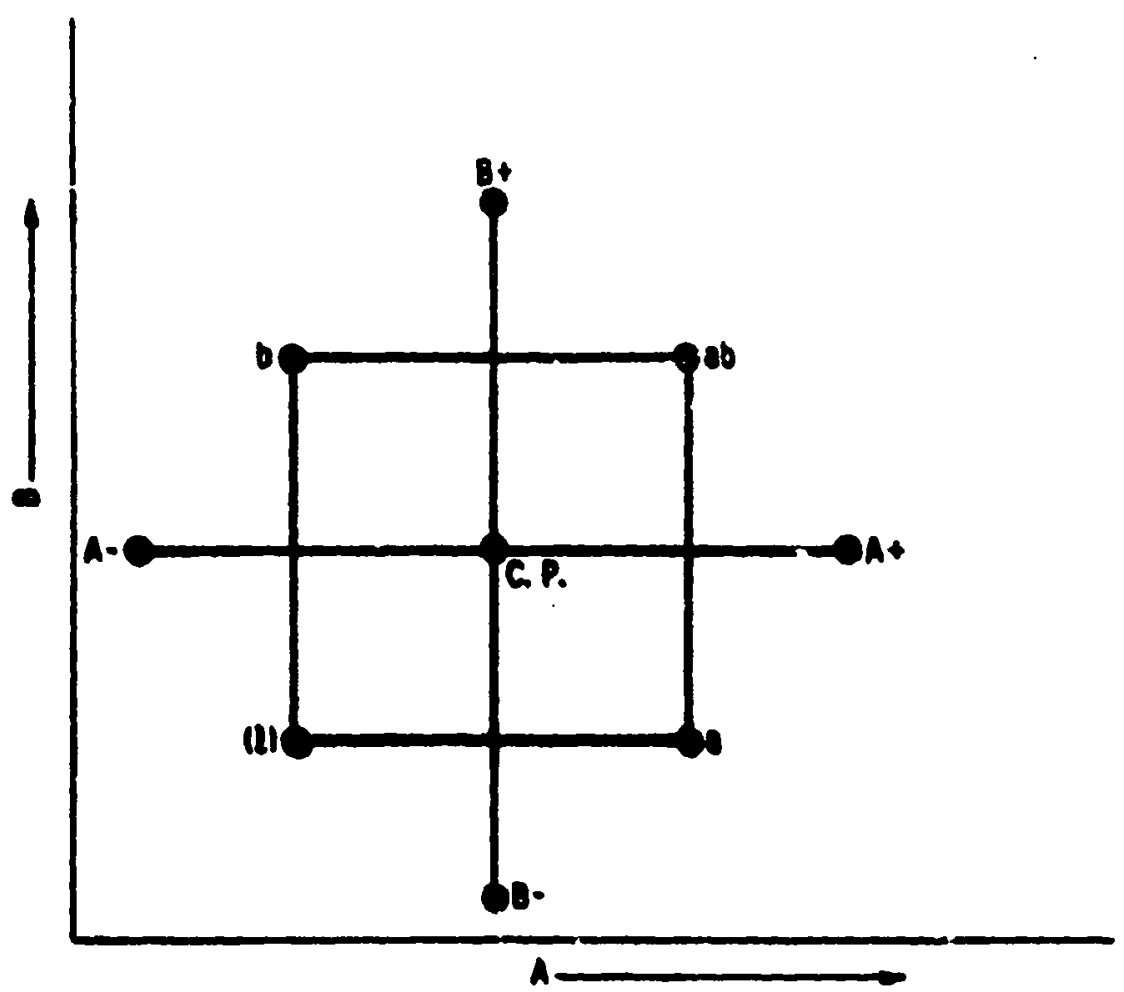

Flgure 2. A central composito fectorial ensign for two varlables, $A$ and $B$. At and 8t donote axtal or star points; C.P. donotes a center point: and 4. b. the and (l) dencte cubs points. 


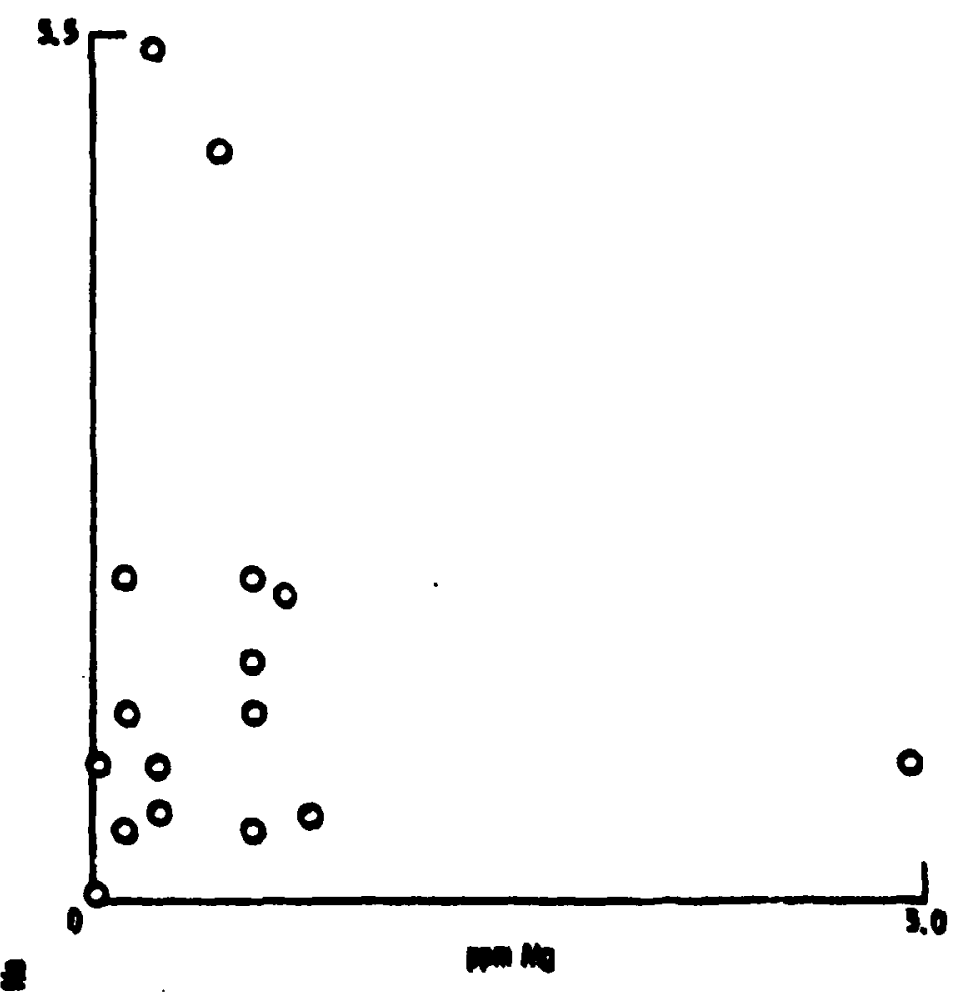

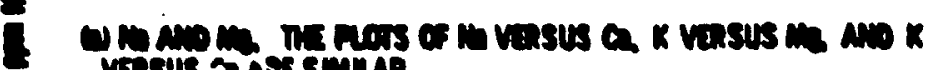
Vensuls so are smmar.

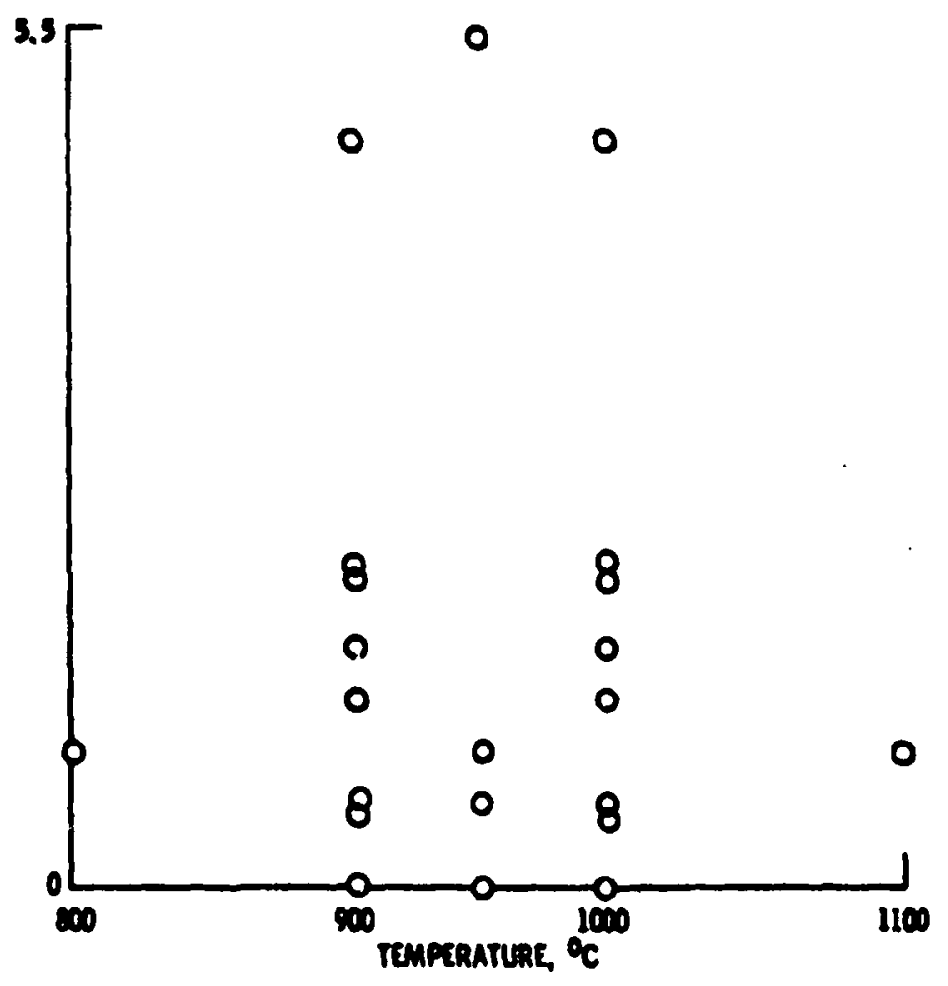

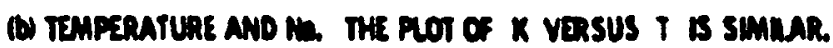

Plgure 2 - The seape of the propran. 


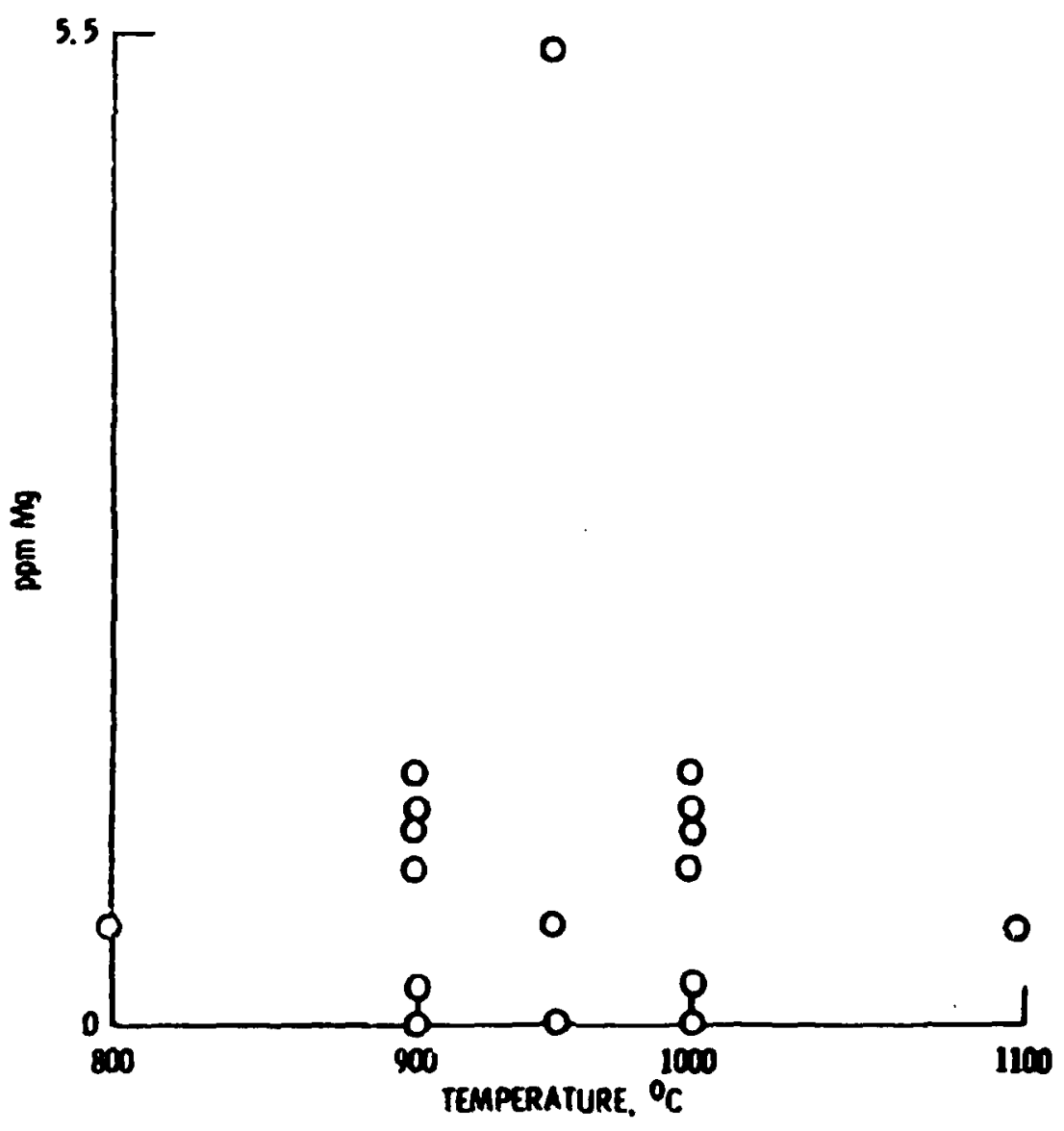

(C) TEMPERATURE ANO iHy. THE PLOT OF CO VERSUS I IS SMMLAR.

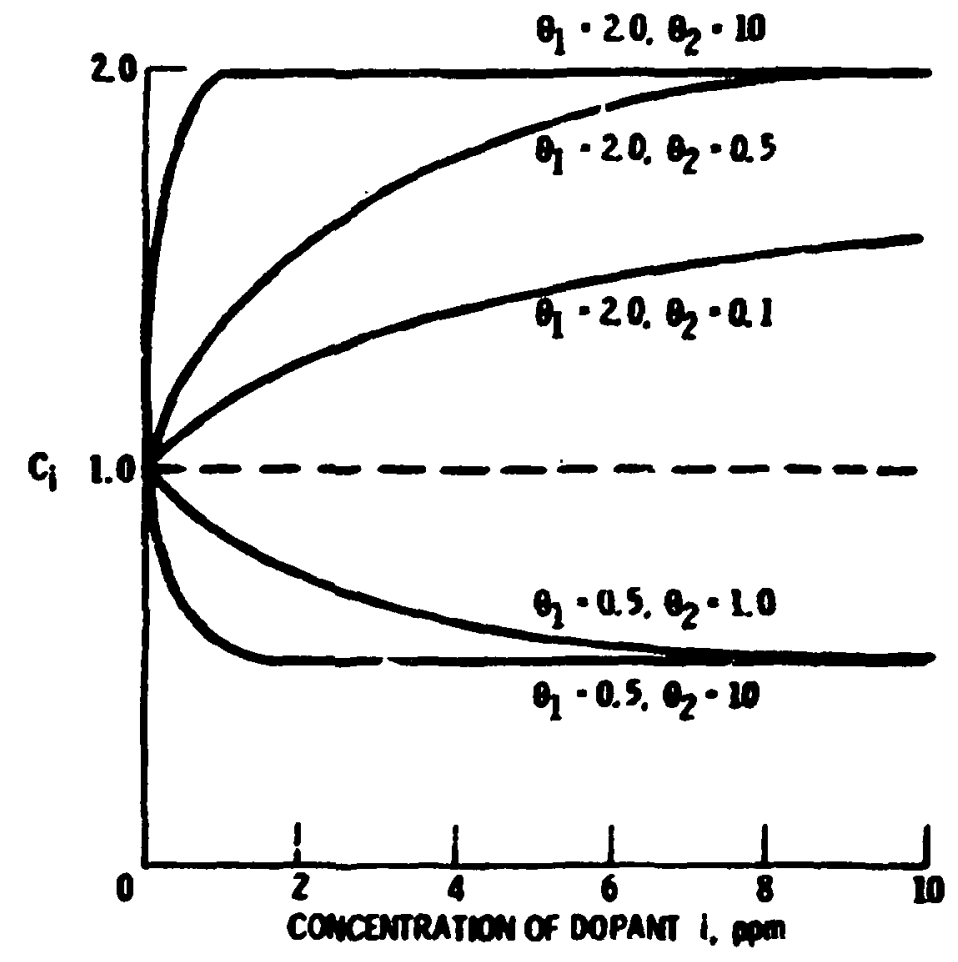

Figure 4 - The response of $c_{i}$ ts concentration of cenemt

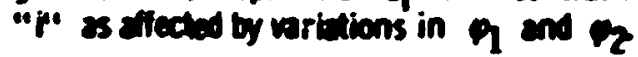

figure 3. - concluded. 

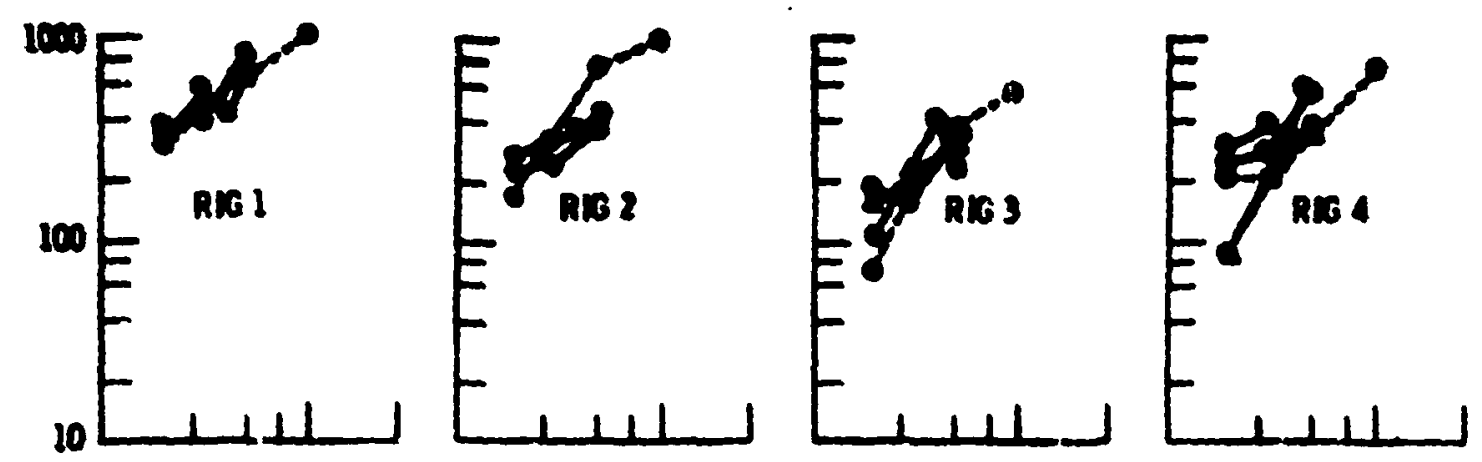

(a) IN-10n
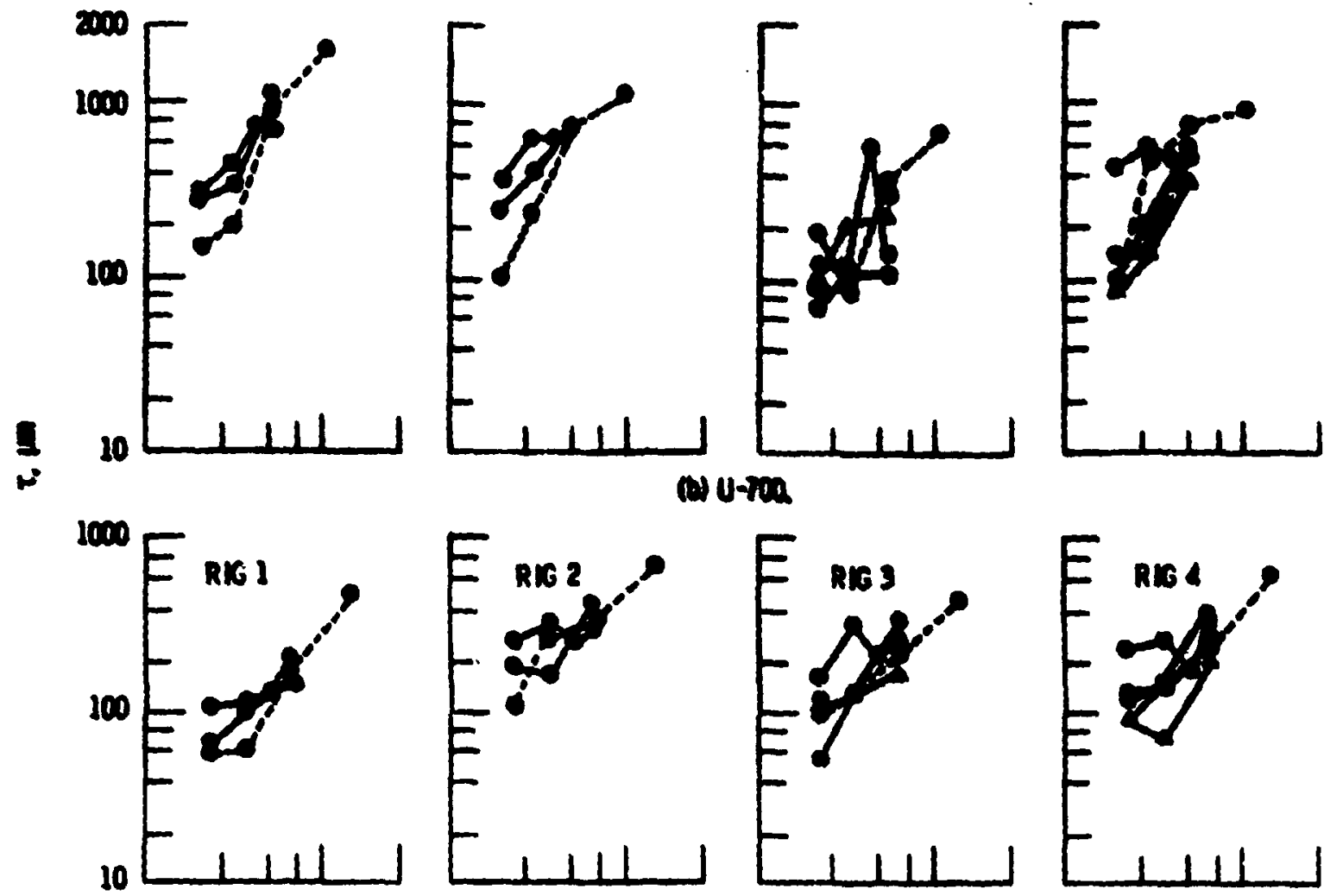

(c)IN-792
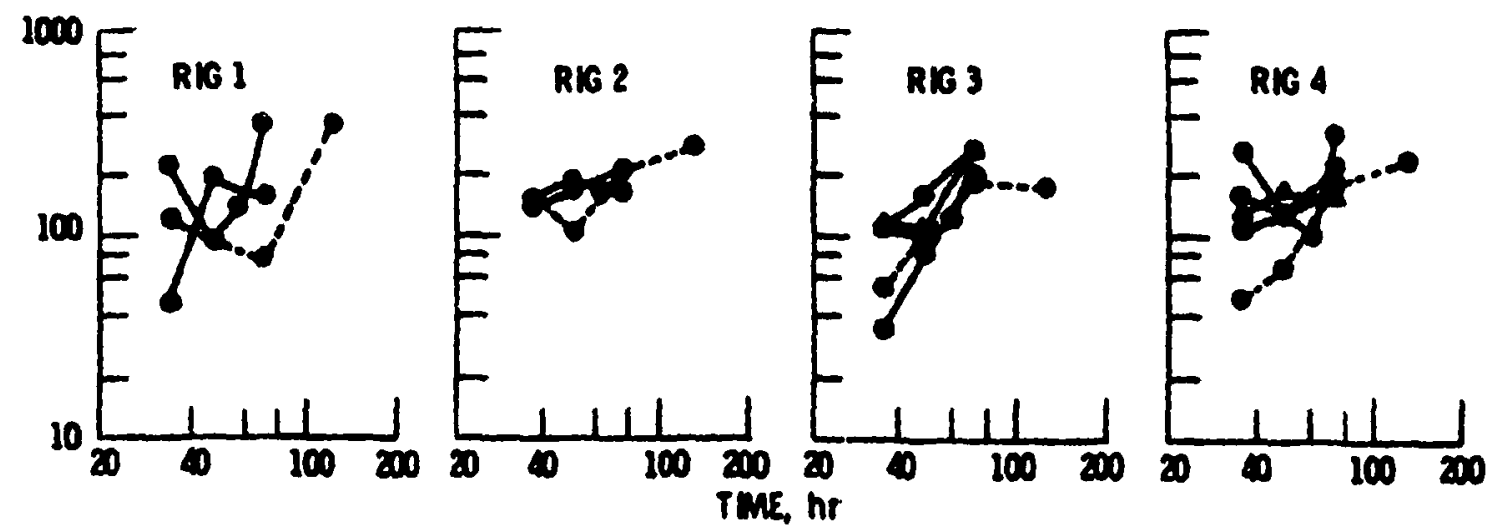

(d) MAR M-SOS.

Figure 5. - Efects of rig and ime on the center point matul recession. 


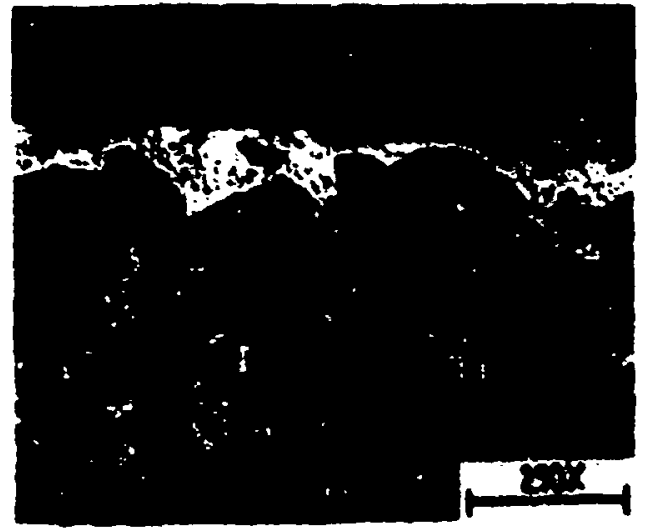

\section{CORROSTON PRODUCTS}

EHRAPPDi mal

OEPLETON ZOHE + SULFWES

(a) whes.

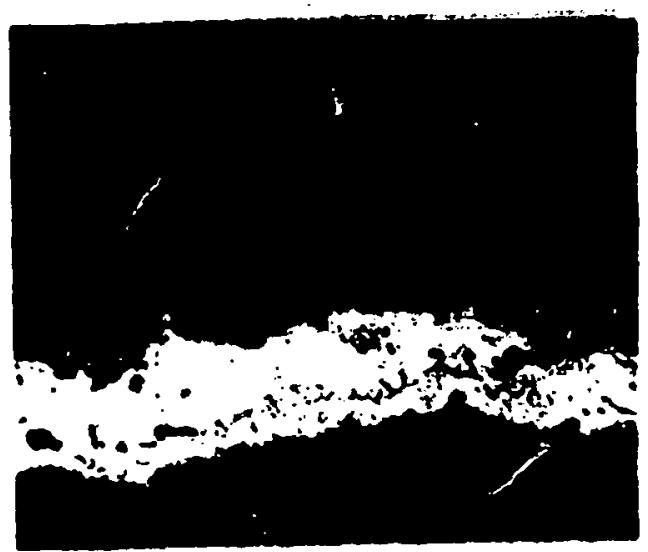

ConRosicy Prooucts

LUAFECID MTAL

\section{connosion prooucts}

DEPLETON ZONE +

SULFIDES

UNAFFECTED METAL

(b) $U-700$.

Figure 6. - Microstructural aftack shter 200 one-Hour cycles under center point condilions. $1950^{\circ} \mathrm{C}, 0.90 \mathrm{Na}, 5.9 \mathrm{~K}, 0.45 \mathrm{Ca}, 0.45 \mathrm{Mg} 3.21 \mathrm{Cl}$ )

$$
\begin{aligned}
& \text { :RIGINAL PAGE IO } \\
& \text { OF POOK PUALIN }
\end{aligned}
$$




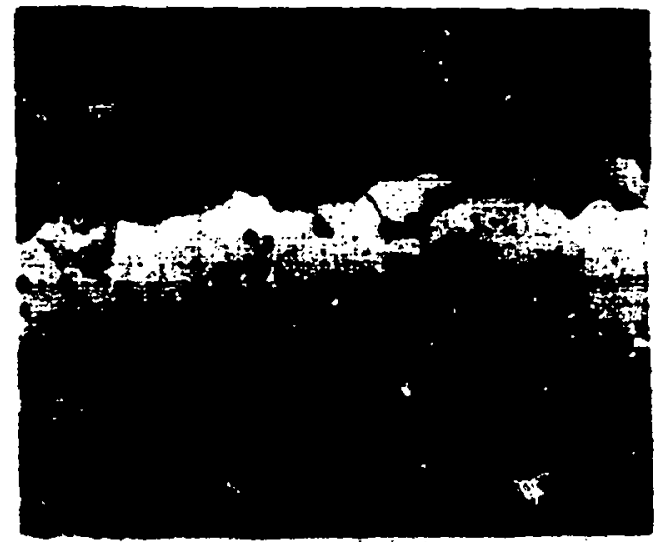

CORROSION PRODUCTS

DITAPPDi Matal

DEPLETION ZONE

sutribs

INFFבT2 METAL

tetsers

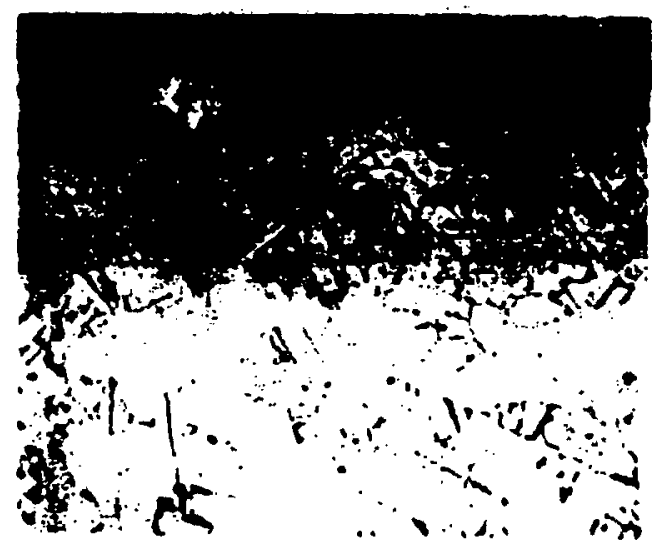

coniosm provoucts

GRAN BOUMDARY +

PERTRATION

UNAFFCTED METAL

MAR M-509

Flgure 6. - Concluded. 


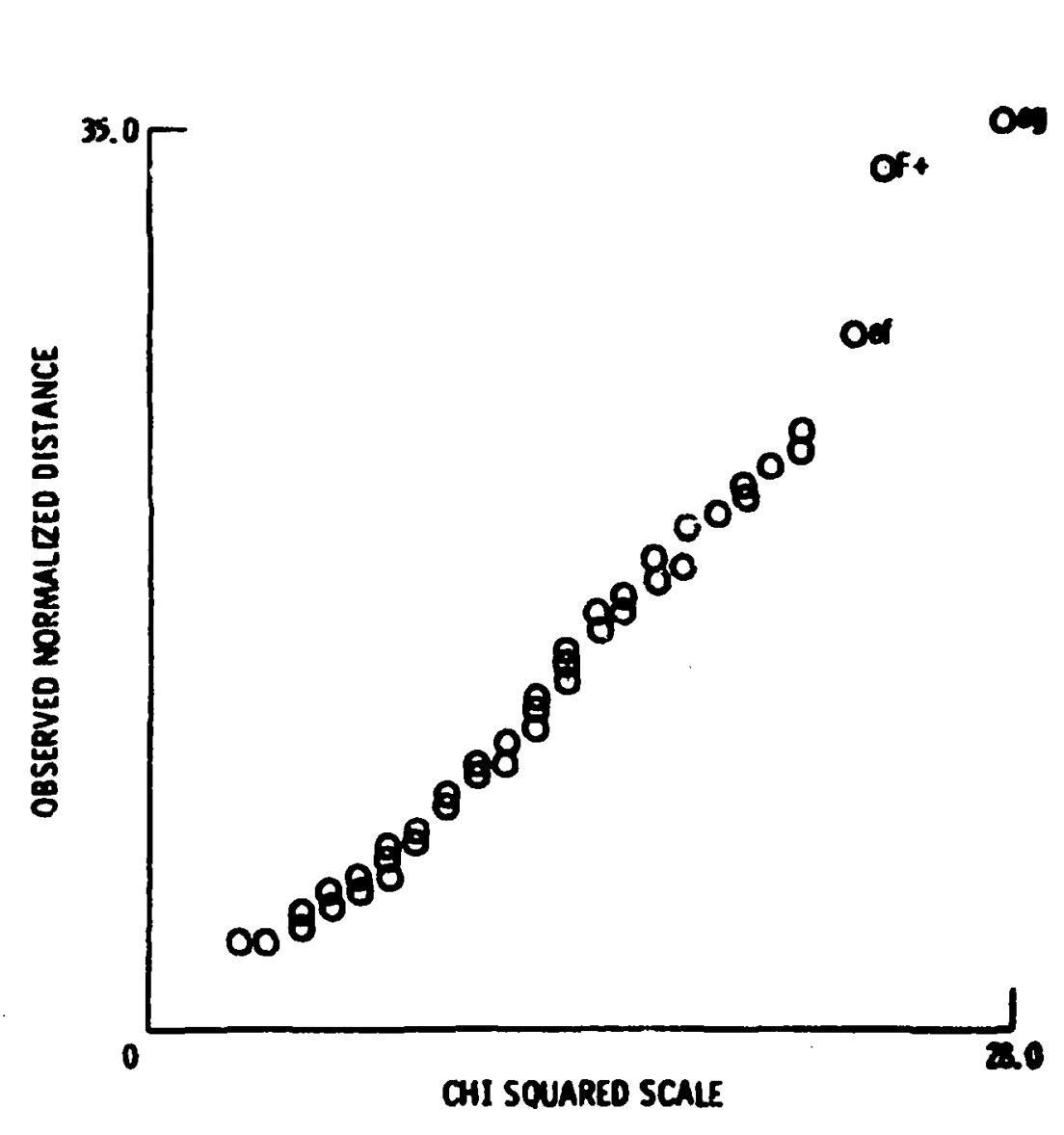

Figure 7. - Probability plot of pass 1 residuat.

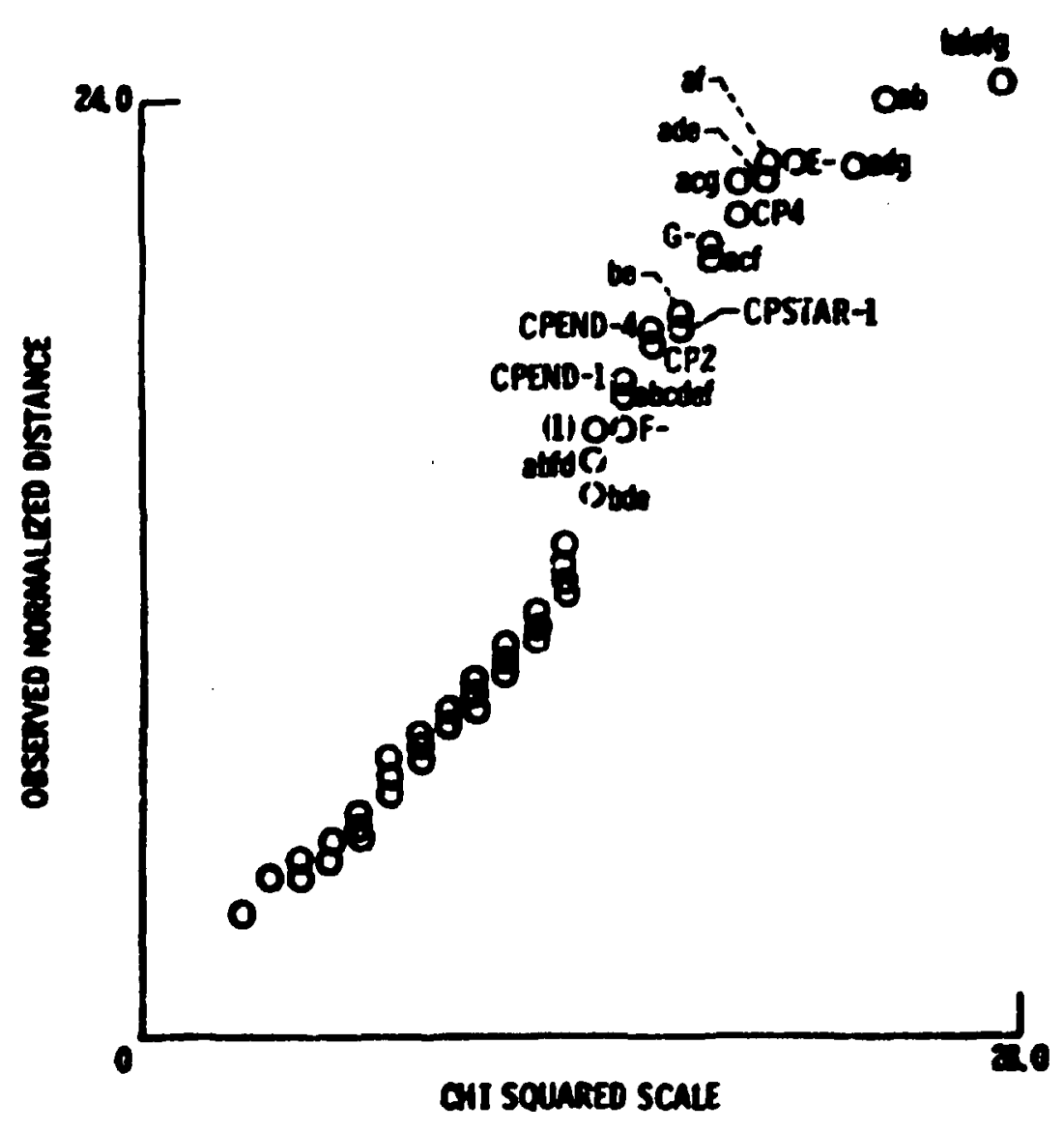

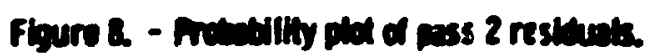




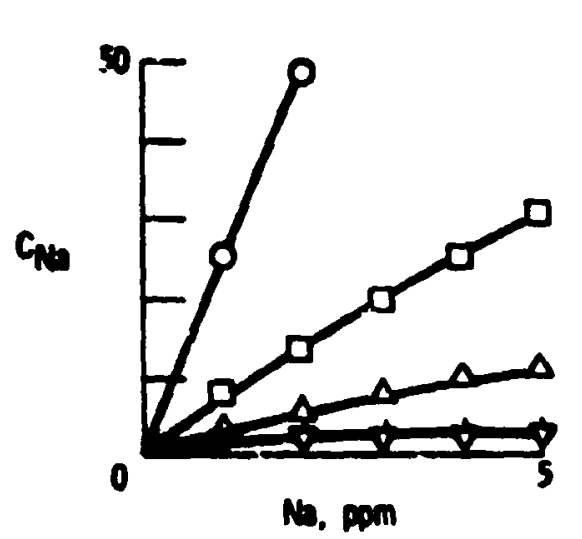

a) soonm

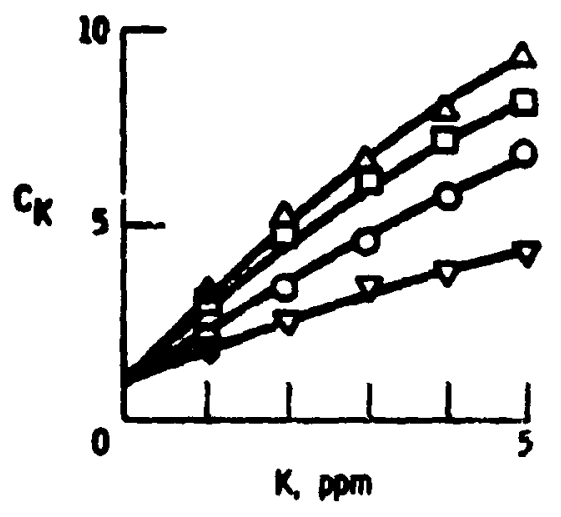

(b) POTASSNum

Figure 9. - Efect al concontration on $C_{p}$.

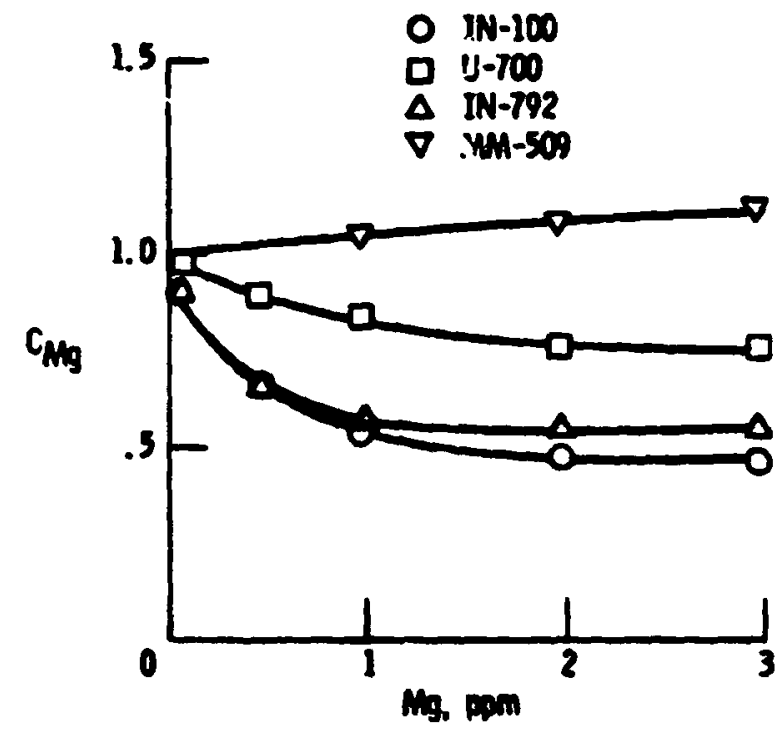

(c) magresulu

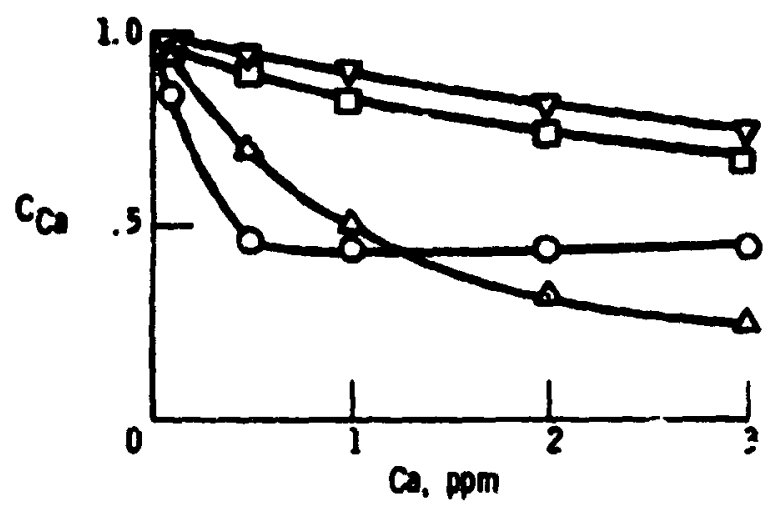

(d) CALCIUM.

Figure 9. - Continued.

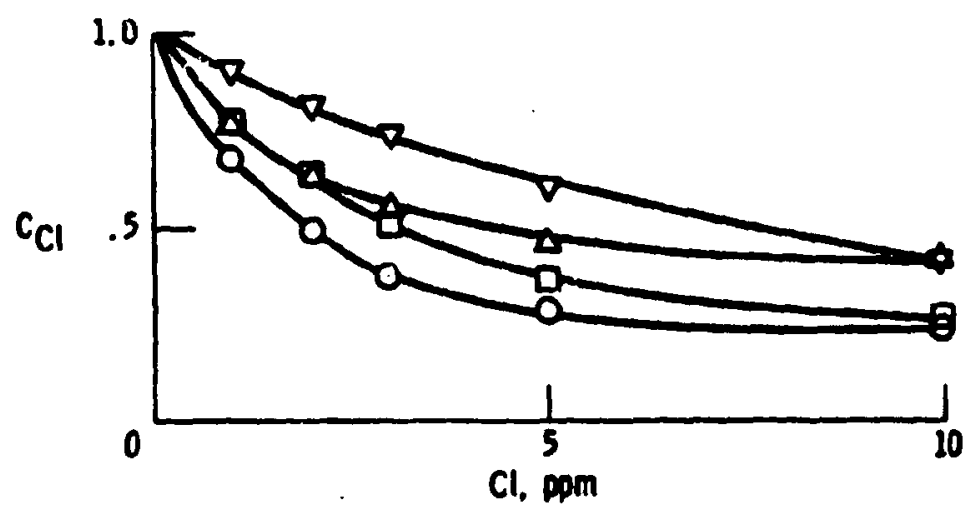

(6) CHLORNE.

Figure 9. - Concluded. 


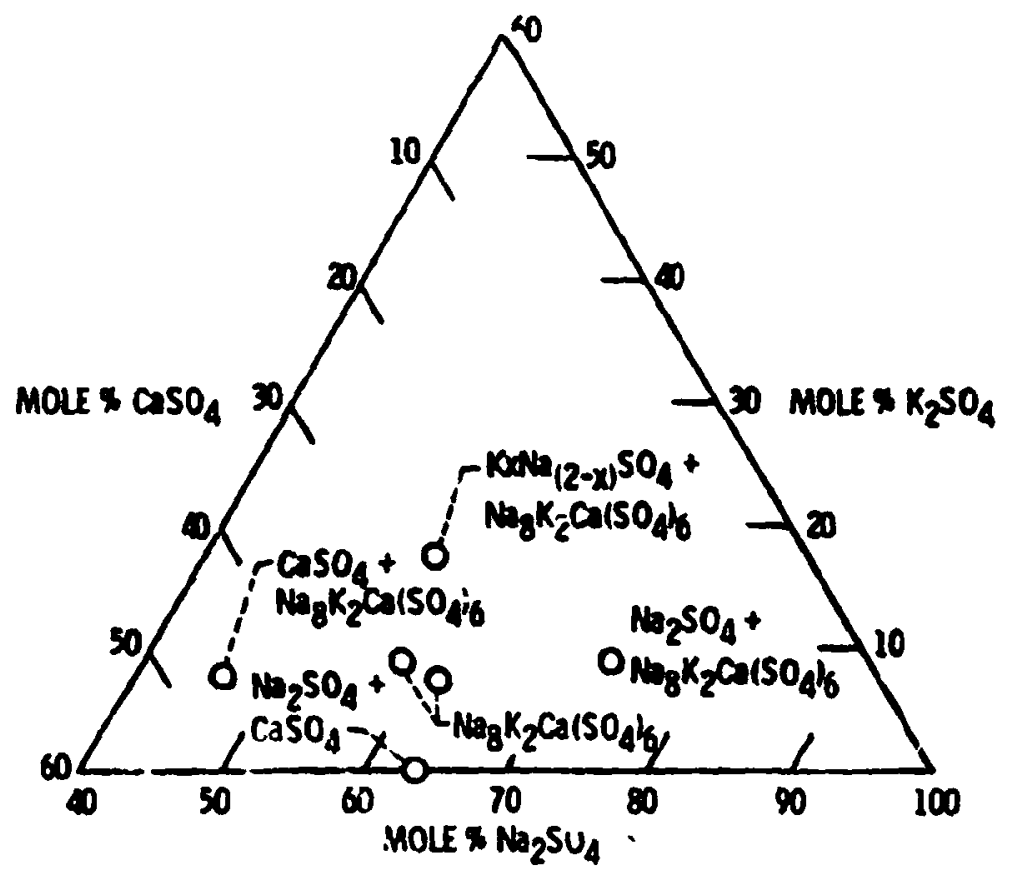

Figure 10. - Sulfate phase map. 